\title{
Active Zone Proteins RIM $1 \alpha \beta$ Are Required for Normal Corticostriatal Transmission and Action Control
}

\author{
David A. Kupferschmidt, ${ }^{1,2}$ Shana M. Augustin, ${ }^{1}$ Kari A. Johnson, ${ }^{1}$ and David M. Lovinger ${ }^{1}$ \\ ${ }^{1}$ Section on Synaptic Pharmacology \& In Vivo Neural Function, Laboratory for Integrative Neuroscience, National Institute on Alcohol Abuse and \\ Alcoholism, National Institutes of Health, Rockville, Maryland 20852, and ${ }^{2}$ Integrative Neuroscience Section, National Institute of Neurological Disorders \\ and Stroke, National Institutes of Health, Bethesda, Maryland 20892
}

\begin{abstract}
Dynamic regulation of synaptic transmission at cortical inputs to the dorsal striatum is considered critical for flexible and efficient action learning and control. Presynaptic mechanisms governing the properties and plasticity of glutamate release from these inputs are not fully understood, and the corticostriatal synaptic processes that support normal action learning and control remain unclear. Here we show in male and female mice that conditional deletion of presynaptic proteins RIM1 $\alpha \beta$ (RIM1) from excitatory cortical neurons impairs corticostriatal synaptic transmission in the dorsolateral striatum. Key forms of presynaptic G-protein-coupled receptormediated short- and long-term striatal plasticity are spared following RIM1 deletion. Conditional RIM1 K0 mice show heightened novelty-induced locomotion and impaired motor learning on the accelerating rotarod. They further show heightened self-paced instrumental responding for food and impaired learning of a habitual instrumental response strategy. Together, these findings reveal a selective role for presynaptic RIM1 in neurotransmitter release at prominent basal ganglia synapses, and provide evidence that RIM1-dependent processes help to promote the refinement of skilled actions, constrain goal-directed behaviors, and support the learning and use of habits.
\end{abstract}

Key words: action; corticostriatal; learning; plasticity; RIM1; transmission

\section{Significance Statement}

Our daily functioning hinges on the ability to flexibly and efficiently learn and control our actions. How the brain encodes these capacities is unclear. Here we identified a selective role for presynaptic proteins RIM1 $\alpha \beta$ in controlling glutamate release from cortical inputs to the dorsolateral striatum, a brain structure critical for action learning and control. Behavioral analysis of mice with restricted genetic deletion of $\operatorname{RIM} 1 \alpha \beta$ further revealed roles for $\mathrm{RIM} 1 \alpha \beta$-dependent processes in the learning and refinement of motor skills and the balanced expression of goal-directed and habitual actions.

\section{Introduction}

The capacities to select, refine, and automatize actions arise from concerted activity and plasticity of multiple, interconnected neural networks. Central to these networks is the dorsal striatum, the primary input nucleus of the basal ganglia (Balleine et al., 2007; Heilbronner et al., 2016). Excitatory projections emanating

Received July 26, 2018; revised Nov. 13, 2018; accepted Dec. 4, 2018.

Author contributions: S.M.A., K.A.J., and D.M.L. edited the paper. D.A.K. and D.M.L. designed research; D.A.K., S.M.A., and K.A.J. performed research; D.A.K. and K.A.J. analyzed data; D.A.K. wrote the paper.

This work was supported by National Institute on Alcohol Abuse and Alcoholism Division of Intramural Clinical and Biological Research ZIA AA000416, Natural Sciences and Engineering Research Council postdoctoral fellowship 438487-13 to D.A.K., and National Institute of General Medical Sciences PRAT Fellowship and K99 AA025403 to K.A.J. We thank all members of the D.M.L. laboratory for helpful discussions about the present experiments and manuscript; Guoxiang Luo for help with mouse genotyping; and the Fishers Lane Animal Care staff for excellent animal husbandry.

The authors declare no competing financial interests.

Correspondence should be addressed to David M. Lovinger at lovindav@mail.nih.gov.

https://doi.org/10.1523/JNEUROSCI.1940-18.2018

Copyright $\odot 2019$ the authors $\quad 0270-6474 / 19 / 391457-14 \$ 15.00 / 0$ broadly from cerebral cortex, thalamus, and amygdala innervate the dorsal striatum in complex patterns (Kelley et al., 1982; McGeorge and Faull, 1989; Smith et al., 2004; Hintiryan et al., 2016; Hunnicutt et al., 2016), contributing to functional heterogeneity across its various subregions. For example, the learning and use of goal-directed action strategies preferentially recruit and rely on dorsomedial striatal subregions (Barnes et al., 2005; Yin et al., 2005a,b; Thorn et al., 2010; Corbit et al., 2013; Gremel and Costa, 2013; Hart et al., 2018), whereas habitual strategies and skilled action patterns preferentially engage and depend on intact dorsolateral subregions (Yin et al., 2004, 2006, 2009; Dias-Ferreira et al., 2009; Thorn et al., 2010; Kupferschmidt et al., 2017). By gating and integrating diverse inputs across these subregions, the dorsal striatum functions to facilitate adaptive behavioral control (Graybiel and Grafton, 2015; Rueda-Orozco and Robbe, 2015; Peak et al., 2018).

Cortical inputs provide a primary source of excitatory drive of dorsal striatal neurons (Wilson, 1995; Huerta-Ocampo et al., 
2014); thus, dynamic changes in corticostriatal transmission are considered key determinants of dorsal striatum function and adaptive actions. Postsynaptic plasticity at putative corticostriatal synapses has been well established to contribute to action learning and control (Costa et al., 2004; Barnes et al., 2005; Yin et al., 2005a, 2006, 2009; Dang et al., 2006; Pittenger et al., 2006; Hawes et al., 2015; Santos et al., 2015). Glutamate release from corticostriatal terminals is also potently modulated by various presynaptic signaling and plasticity processes (Calabresi et al., 1990; Lovinger, 1991; Atwood et al., 2014; Park et al., 2014; Kupferschmidt and Lovinger, 2015). Ex vivo electrophysiology and gene deletion studies suggest roles for presynaptic plasticity at corticostriatal terminals in skill learning (Barnes et al., 2005; Kheirbek et al., 2009; Yin et al., 2009; Hawes et al., 2015), and manipulations of presynaptic corticostriatal receptor function bias the learning and use of goal-directed and habitual action strategies (Nazzaro et al., 2012; Gremel et al., 2016). Notably, loss of presynaptic cannabinoid-1 receptor (CB1R)-dependent long-term depression (LTD) of excitatory transmission in the dorsolateral striatum (DLS) has been proposed to promote habit formation (Nazzaro et al., 2012), whereas endocannabinoid signaling in dorsomedial striatum fosters habit formation (Gremel et al., 2016). Furthermore, in vivo monitoring of corticostriatal input function has revealed presynaptic activity dynamics that encode and predict action learning (Kupferschmidt et al., 2017). Despite these advances, little is known about the synaptic mechanisms through which corticostriatal transmission supports action learning and control.

Rab3-interacting molecules (RIMs) are presynaptic scaffolding proteins that coordinate key active zone processes involved in synaptic transmission (Südhof, 2013). RIMs form the core of a macromolecular complex that recruits voltage-gated calcium channels to active zones, docks synaptic vesicles to the exocytotic machinery, and primes them for release (Wang et al., 1997; Coppola et al., 2001; Hibino et al., 2002; Sun et al., 2003; Deng et al., 2011; Han et al., 2011; Kaeser et al., 2011). Seven different RIM isoforms are encoded by four genes (Rims1-4), the first of which gives rise to isoforms RIM $1 \alpha$ and RIM1 $\beta$ (collectively, RIM1) (Kaeser et al., 2008a). These isoforms are expressed widely in brain, with particularly high mRNA and protein levels in forebrain and cerebellar structures (Schoch et al., 2006; Kaeser et al., 2008a). Global and conditional knockout (KO) of RIM1 isoforms has revealed synapse-specific roles for the proteins in synaptic transmission and presynaptically expressed plasticity (Castillo et al., 2002; Schoch et al., 2002; Calakos et al., 2004; Chevaleyre et al., 2007; Fourcaudot et al., 2008; Kaeser et al., 2008b; Grueter et al., 2010). For example, RIM1 $\alpha$ deletion selectively impairs synaptic transmission and short-term plasticity at hippocampal Schaffer collateralCA1 synapses (Schoch et al., 2002), whereas mossy fiber synapses show selective deficits in long-term plasticity after such deletion (Castillo et al., 2002; Yang and Calakos, 2010). These and other synaptic phenotypes have been linked to behavioral abnormalities following RIM1 deletion, including altered maternal behavior, fear and spatial learning, locomotion, and prepulse inhibition (Schoch et al., 2002; Powell et al., 2004; Blundell et al., 2010; Haws et al., 2012). Despite the importance of corticostriatal transmission and its presynaptic regulation to dorsal striatal function, the contributions of RIM1 to these synaptic processes have yet to be tested. Moreover, the discrete presynaptic proteins and processes within corticostriatal inputs that support action learning and control remain poorly understood.

Here we show that conditional deletion of RIM1 from cortical pyramidal neurons, including corticostriatal projection neurons, impairs excitatory transmission in the DLS, but spares forms of GPCR-mediated short- and long-term striatal plasticity. Conditional RIM1 KO mice show heightened novelty-induced locomotion and impaired motor learning on the accelerating rotarod. They further show heightened instrumental responding for food under higher-effort conditions and impaired expression of habitual food responding. These findings implicate RIM1-dependent processes in corticostriatal transmission and in the learning and control of motivated behavior.

\section{Materials and Methods}

Mice

All mice used in these experiments were obtained from The Jackson Laboratory and backcrossed onto a C57BL/6J background (stock $\# 000664)$ for at least 5 generations. Floxed RIM1 mice (RIM1 ${ }^{f l / f l}$, stock \#015832) (Kaeser et al., 2008a) that carry loxP sites flanking exon 6 of the RIM1 gene were bred with Emxl::Cre mice (stock \#005628) (Gorski et al., 2002) that express Cre recombinase in the majority of excitatory cells in the neocortex and hippocampus (and sparser populations in some ventral pallial structures) using a 3-stage breeding strategy: (1) Emx1::Cre mice were crossed with $R I M 1^{f l / f l}$ mice; (2) Emx1::Cre;RIM1 $1^{-1+}$ offspring were crossed with RIM ${ }^{f l / f l}$ mice; and (3) Emx $1:: C r e ; R I M 1^{-1-}$ offspring were crossed again with $R I M 1^{f l f l}$ mice. This strategy generated age- and sex-matched littermates with RIM1 either present in $\left(R I M 1^{f l / f l}\right.$; Control) or deleted from $E m x 1^{C r e}$-expressing cells (Emxl::Cre;RIM1 ${ }^{-{ }^{-}}$). Mice were housed in groups of $2-4$ in a humidity- and temperature-controlled colony room on a $12 \mathrm{~h}$ light/dark cycle with ad libitum access to water and food (unless otherwise specified). Mice that underwent testing for novelty-induced locomotion were later tested for motor learning on the accelerating rotarod and prepulse inhibition. Mice tested for homecage locomotion, fixed ratio (FR)/progressive ratio (PR) instrumental training, and fixed/random interval (RI) instrumental training comprised 3 separate cohorts. All procedures conformed to the National Institutes of Health Guide to the care and use of laboratory animals and were approved by the National Institute on Alcohol Abuse and Alcoholism Animal Care and Use Committee.

\section{$q R T-P C R$}

Mice were anesthetized with isoflurane and decapitated, and brains were rapidly removed and rinsed in cold $0.9 \% \mathrm{NaCl}$. Brains were cut into 1 $\mathrm{mm}$ coronal sections using a stainless-steel brain matrix, and samples from $\mathrm{M} 1+\mathrm{M} 2$ motor cortices, dorsal striatum, or thalamus were placed in RNAlater (Invitrogen), stored at $4^{\circ} \mathrm{C}$ for $48 \mathrm{~h}$, then removed from RNAlater and frozen at $-20^{\circ} \mathrm{C}$ before RNA extraction. RNA was extracted using the RNeasy Lipid Tissue Mini Kit (QIAGEN), and RNA concentration was measured using a NanoDrop (Thermo Fisher Scientific). RNA (100 ng) was reverse transcribed using the Quantitect Reverse Transcription Kit (QIAGEN). qPCRs contained $2 \mu \mathrm{l}$ cDNA template, 1 $\mu \mathrm{l}$ predesigned TaqMan Gene Expression Assay (for Rim1, Mm01225745 m1), $10 \mu \mathrm{l}$ TaqMan Fast Advanced Master Mix (both from Thermo Fisher Scientific), and $7 \mu$ l Ultrapure water (Invitrogen). qPCR was run on StepOnePlus system (Thermo Fisher Scientific) and was performed according to the manufacturer's recommended settings: $50^{\circ} \mathrm{C}$ for $2 \mathrm{~min}$, $95^{\circ} \mathrm{C}$ for $2 \mathrm{~min}$, and then 40 cycles of melting at $95^{\circ} \mathrm{C}$ for $1 \mathrm{~s}$ and annealing/extension at $60^{\circ} \mathrm{C}$ for $20 \mathrm{~s}$. Reactions were run in triplicate for 4 or 5 animals per group. Analysis was performed using the $2^{-\Delta \mathrm{CT}}$ method (Schmittgen and Livak, 2008). The $\mathrm{C}_{\mathrm{T}}$ value was determined by identifying the cycle number at which the amplification curve reached a $\Delta \mathrm{Rn}$ threshold set at $0.1(\Delta R n=R n-$ baseline, where $R n$ is the fluorescence of the reporter dye divided by the fluorescence of a passive reference dye). Relative Rim 1 mRNA expression was quantified using Actb as an internal control (Applied Biosystems \#4351315). Thus, $\Delta \mathrm{C}_{\mathrm{T}}=\mathrm{C}_{\mathrm{T}}(\operatorname{Rim1})-\mathrm{C}_{\mathrm{T}}$ (Actb).

\section{Immunohistochemistry}

$R I M 1^{f l f l}$ and Emx1::Cre;RIM1 $1^{-1-}$ mice were transcardially perfused under deep isoflurane anesthesia with $0.1 \mathrm{M}$ PBS and $4 \%$ formaldehyde in PBS, pH 7.4. Brains were collected and postfixed in $4 \%$ formaldehyde at 
$4^{\circ} \mathrm{C}$ for $24 \mathrm{~h}$. The $50 \mu \mathrm{m}$ coronal sections were made using a vibratome. On a revolving platform, sections were incubated in PBST (PBS with $0.2 \%$ Triton X-100) for $2 \mathrm{~h}$, and blocked in 5\% BSA in PBST for $4 \mathrm{~h}$. Slices were then incubated in chicken anti-Neurofilament (Encor Biotechnology, catalog \#CPCA-NF-H, 1:40,000) with rabbit anti-mu opioid receptor (Immunostar, 24216, 1:4000), rabbit anti-parvalbumin (Swant, PV27, 1:1000), or rabbit anti-cannabinoid-1 receptor (CB1R; Synaptic Systems, 258003, 1:1000) antibodies in PBST for $12 \mathrm{~h}$ at $4^{\circ} \mathrm{C}$. Following three $1 \mathrm{~h}$ washes in PBST, slices were incubated in AlexaFluor-488 goat anti-chicken (Invitrogen, A-11039, 1:2000), AlexaFluor-488 goat antirabbit (Invitrogen, A-11034, 1:1000), and/or AlexaFluor-568 goat antirabbit (Invitrogen, A-11011, 1:1000) antibodies in PBST for $12 \mathrm{~h}$ at $4^{\circ} \mathrm{C}$. Following a $1 \mathrm{~h}$ wash in PBST containing DAPI (Invitrogen, D3571, 1:20,000) and three $1 \mathrm{~h}$ washes in PBS, sections were mounted on Superfrost Plus slides (Daigger, EF15978Z) using Fluoromount Aqueous Mounting Medium (Sigma-Aldrich, F4680), coverslipped, and imaged using Carl Zeiss AxioVision LE 4.3 software with a Carl Zeiss Axiocam on a Carl Zeiss SteREO Lumar microscope. Brightness was uniformly adjusted in each image for presentation.

\section{Electrophysiology}

Brain slice preparation for electrophysiology. Following isoflurane anesthesia, RIM1 fl/fl and Emx1::Cre;RIM1 ${ }^{-1-}$ mice (P18-P50) were decapitated, and brains were rapidly removed and submerged in ice-cold cutting solution containing the following (in $\mathrm{mM}$ ): $30 \mathrm{NaCl}, 4.5 \mathrm{KCl}, 1$ $\mathrm{MgCl}_{2}, 26 \mathrm{NaHCO}_{3}, 1.2 \mathrm{NaH}_{2} \mathrm{PO}_{4}, 10$ glucose, and 194 sucrose, continuously bubbled with $95 \% \mathrm{O}_{2} / 5 \% \mathrm{CO}_{2}$. Slices were submerged in aCSF containing the following (in mM): $124 \mathrm{NaCl}, 4.5 \mathrm{KCl}, 2 \mathrm{CaCl}_{2}, 1 \mathrm{MgCl}_{2}$, $26 \mathrm{NaHCO}_{3}, 1.2 \mathrm{NaH}_{2} \mathrm{PO}_{4}$, and 10 glucose, in a holding chamber and continuously bubbled with $95 \% \mathrm{O}_{2} / 5 \% \mathrm{CO}_{2}$. Slices were incubated for $30 \mathrm{~min}$ at $32^{\circ} \mathrm{C}$ and then held at room temperature for $1-5 \mathrm{~h}$ before whole-cell recordings.

Whole-cell voltage-clamp recordings (excluding depolarization-induced suppression of excitation [DSE] and DHPG experiments). Individual hemisected slices were moved to a custom recording chamber where they were submerged in and continuously perfused with $30^{\circ} \mathrm{C}-32^{\circ} \mathrm{C}$ aCSF containing picrotoxin $(50 \mu \mathrm{M})$ at a rate of $\sim 1.5 \mathrm{ml} / \mathrm{min}$. Borosilicate glass pipettes (2.5-4.0 $\mathrm{M} \Omega$ resistance in bath) were filled with internal solution (295-310 mOsm, $\mathrm{pH} 7.3$ ) containing the following (in $\mathrm{mm}$ ): 120 $\mathrm{CsMeSO}_{3}, 5 \mathrm{NaCl}, 10$ tetraethylammonium-Cl, 10 HEPES, 5 QX-314, 1.1 EGTA, 0.3 Na-GTP, and $4 \mathrm{Mg}$-ATP. Slices were visualized on a Olympus BX51WI microscope with a $40 \times / 0.8$ NA water-immersion objective. EPSCs were recorded from medium-sized spiny projection neurons (MSNs) held at $-60 \mathrm{mV}$ using a Multiclamp 700A amplifier and Digidata 1332A (Molecular Devices). Recordings were filtered at $2 \mathrm{kHz}$ and digitized at $10 \mathrm{kHz}$ using Clampex 10.3 software (Molecular Devices). A concentric bipolar stimulating electrode (FHC, CBAEC75), controlled by an isolation unit (Digitimer, DS3) and Clampex 10.3, was placed at the border of the DLS and the overlying white matter. Electrical pulses were delivered every $20 \mathrm{~s}$. Stimulation duration $(40-80 \mu \mathrm{s})$ and intensity (40$100 \mu \mathrm{A}$ ) were adjusted to yield EPSC amplitudes of $200-500$ pA. Experiments were discarded if series resistance varied by $>20 \%$ or increased $>25 \mathrm{M} \Omega$. Data were analyzed using Clampfit 10.3 .

Whole-cell voltage-clamp recordings (DSE experiments). Recordings were performed as described above, with the following exceptions. Recording pipettes were filled with a potassium-based internal solution containing the following (in $\mathrm{mm}$ ): $120 \mathrm{~K}$-gluconate, $4 \mathrm{NaCl}, 20 \mathrm{KCl}, 10$ HEPES, $0.4 \mathrm{Na}-\mathrm{GTP}$, and $4 \mathrm{Mg}$-ATP, $\mathrm{pH}$ adjusted to 7.25 using $\mathrm{KOH}$. Neurons were held at $-70 \mathrm{mV}$, and electrical pulses were delivered every $5 \mathrm{~s}$. EPSC amplitudes were monitored for $50 \mathrm{~s}$ before and $100 \mathrm{~s}$ after DSE induction. DSE was induced by depolarizing the neuron to $30 \mathrm{mV}$ for $10 \mathrm{~s}$. The data were averaged from 3 trials per cell. For each trial, EPSC amplitudes were normalized to the average baseline amplitude, and between-group comparisons were made on the first EPSC following DSE induction.

Whole-cell voltage-clamp recordings (DHPG experiments). EPSCs were recorded through pipettes of $3-5 \mathrm{M} \Omega$ in MSNs held at $-50 \mathrm{mV}$. EPSCs were evoked every 20 s by a tungsten bipolar stimulating electrode (FHC) with a tip separation of $505 \mu \mathrm{m}$ placed in the DLS near the border of the external capsule adjacent to the recorded neuron. Stimulation intensity was adjusted to yield EPSC amplitudes of 200-400 pA. Experiments were discarded if series resistance varied by $>15 \%$ or increased $>20 \mathrm{M} \Omega$.

\section{Homecage locomotion}

$R_{I M} 1^{f l f l}$ and Emx1::Cre;RIM1 $1^{-1-}$ mice were individually housed in standard homecages. Mice were then habituated to the locomotor testing room for $1 \mathrm{~h} / \mathrm{d}$ for $3 \mathrm{~d}$ immediately following onset of the dark cycle. On the fourth day, mice were moved to the locomotor testing room for $1 \mathrm{~h}$ and then placed into a clean homecage. Horizontal activity was monitored using a photobeam-based system (San Diego Instruments) for 72 consecutive hours, across normal light-dark cycles.

\section{Novel cage locomotion}

$R_{I M 1^{f l f l}}$ and Emx1::Cre;RIM1 ${ }^{-1-}$ mice were habituated to the locomotor testing room for $1 \mathrm{~h} / \mathrm{d}$ for $3 \mathrm{~d} 1-2 \mathrm{~h}$ following onset of the light cycle. On the fourth day, mice were individually placed in clear Plexiglas rectangular chambers with minimal bedding, and horizontal activity was monitored using the photobeam-based tracking system for $2 \mathrm{~h} / \mathrm{d}$ for $6 \mathrm{~d}$. For one cohort of mice, used chambers were exchanged daily with clean chambers ("novel" cage each day); for another cohort, chambers remained unchanged across the $6 \mathrm{~d}$ of locomotor testing.

\section{Prepulse inhibition}

Prepulse inhibition was assessed in RIM fl/fl and Emx1::Cre;RIM1 ${ }^{-1-}$ mice using procedures similar to those used previously (Blundell et al., 2010 ) in RIM1 $\alpha$ KO mice. A startle chamber (San Diego Instruments) was fixed above a piezoelectric accelerometer and enclosed in a soundattenuating box (Med Associates). Acoustic stimuli were delivered by a speaker mounted inside the box, $20 \mathrm{~cm}$ above the startle chamber. Chamber sensitivity and sound levels were calibrated before the experiment. Each startle response was recorded over a $65 \mathrm{~ms}$ period and quantified in arbitrary units. Mice underwent 62 trials of five trial types across a $22 \mathrm{~min}$ session: pulse alone ( $40 \mathrm{~ms}$ pulse of $120 \mathrm{~dB}$ white noise), three different prepulse/pulse trials ( $20 \mathrm{~ms}$ prepulse of 4,8 , or $16 \mathrm{~dB}$ above background noise level of $70 \mathrm{~dB}$ preceding $100 \mathrm{~ms}, 120 \mathrm{~dB}$ pulse; onset to onset), and no stimulus. Trials were presented pseudo-randomly with an average intertrial interval of $15 \mathrm{~s}$ (7-23 s). A 5 min acclimation period preceded testing in four blocks of trials. Blocks 1 and 4 consisted of six pulse-alone trials; blocks 2 and 3 contained six pulse-alone trials, five of each level of prepulse/pulse, and five no-stimulus trials. Prepulse inhibition was assessed as the percentage of decrease in startle amplitude in prepulse/pulse trials compared with pulse-alone trials.

\section{Accelerating rotarod}

RIM1 $^{\text {flflfl }}$ and Emx1::Cre;RIM1 ${ }^{-1-}$ mice were trained on a rotarod (ENV-575M, Med Associates) that accelerated from 4 to $40 \mathrm{rpm}$ over $300 \mathrm{~s}$. Latency to fall from the rotarod was recorded during 4 trials per day for $3 \mathrm{~d}$, with $15 \mathrm{~min}$ between trials. Individual trials were stopped and latency was recorded if the mouse held onto the rod for two consecutive rotations or reached $40 \mathrm{rpm}$.

\section{Self-paced instrumental training}

Eight identical operant chambers (Med Associates) enclosed in soundand light-attenuating cases were used for instrumental training. Each chamber was equipped with a pellet dispenser that delivered food pellets (F0071, Bioserv) into a recessed food magazine, an infrared photobeam crossing the magazine to allow detection of magazine head entries, two retractable levers to either side of the magazine, a houselight, and a steel rod floor. A computer running Med-PC software (Med Associates) controlled operant chamber events and recorded lever presses and magazine entries.

$R I M 1^{f l / f l}$ and Emx1::Cre;RIM1 ${ }^{-1-}$ mice were food restricted to $90 \%$ $95 \%$ of their free-feeding body weight, and handled daily for $2 \mathrm{~d}$ before training on one of two instrumental paradigms: [1] FR training and PR testing, and [2] RI training and valuation testing.

\section{FR training and $P R$ testing}

Following $2 \mathrm{~d}$ of food restriction and handling, RIM1 $1^{f l / f l}$ and Emx1::Cre; $R I M 1^{-1-}$ mice were given one $15 \mathrm{~min}$ session of magazine training, 
during which food pellets were delivered at random $60 \mathrm{~s}$ intervals for 15 outcomes. Mice were then trained to press one of two available levers for food pellets in daily $90 \mathrm{~min}$ sessions. Responses on the "active" lever resulted in pellet delivery, whereas responses on the "inactive" lever did not. Mice were trained on an FR1 schedule for $5 \mathrm{~d}$ with the potential to earn up to 10 and 20 rewards on training days 1 and 2, respectively, and 30 rewards on days 3-5. Mice were then trained on an FR5 schedule for $2 \mathrm{~d}$, and an FR10 schedule for $2 \mathrm{~d}$, each with the potential to earn 30 rewards/d. Mice were then tested in one session on a PR schedule wherein mice had to press the active lever a progressively increasing number of times $(10,20,25$, $32,40,50$, etc.) (adapted from Richardson and Roberts, 1996) to obtain successive food pellets. The total number of lever presses and the breakpoint achieved (defined as the last series in which a pellet was obtained) were recorded.

\section{RI training and valuation testing}

A separate cohort of RIM1 $1^{f l f l}$ and Emx $1:: C r e$; RIM $1^{-1-}$ mice were food restricted to $90 \%-$ $95 \%$ of their baseline body weight. Following $2 \mathrm{~d}$ of food restriction and handling, mice were given one 15 min session of magazine training, during which food pellets were delivered at random $60 \mathrm{~s}$ intervals for 15 outcomes. Mice were then trained to press a single lever for food pellets in daily 90 min sessions on FR 1 for $4-5$ $\mathrm{d}$, RI30 for $2 \mathrm{~d}$, and RI60 for $4 \mathrm{~d}$. One to $3 \mathrm{~h}$ following each training session, mice were given $1 \mathrm{~h}$ access to a $20 \%$ sucrose solution in their homecages.

Valuation testing was conducted on the $2 \mathrm{~d}$ following training. On the valued day, mice were given ad libitum access to the sucrose solution for $1 \mathrm{~h}$ before a 5 min unreinforced session in the operant boxes. On the devalued day, mice were given ad libitum access to the food pellets previously earned by lever pressing for $1 \mathrm{~h}$ before a $5 \mathrm{~min}$ unreinforced session in the operant boxes.

Drugs

Picrotoxin (Sigma-Aldrich) was dissolved directly in aCSF. LY379268 and (RS)-3,5-DHPG (Tocris Bioscience) were prepared in distilled $\mathrm{H}_{2} \mathrm{O}$ and aCSF, respectively, and diluted to their final concentrations in aCSF. AM251 (Tocris Bioscience) was prepared in DMSO (Sigma-Aldrich) and diluted to its final concentration in aCSF containing $\beta$-cyclodextrin $(6 \%$ $\mathrm{w} / \mathrm{v}$; TCI America) as a carrier. The final concentration of DMSO was $<0.1 \%$.

\section{Statistics}

Data are mean \pm SEM. One-sample Student's $t$ tests were used to compare a single genotype (RIM1 $1^{f l f l}$ or Emx1::Cre;RIM1 ${ }^{-{ }^{-}}$) to a theoretical mean (e.g., 100\% EPSC amplitude baseline). Two-tailed paired or unpaired Student's $t$ tests were used to compare RIM1 ${ }^{f l f l}$ or Emxl::Cre;

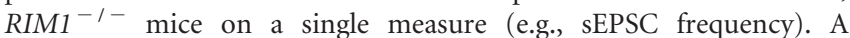
nonparametric Mann-Whitney test was used to compare RIM1 $1^{f l f l}$ or Emx1::Cre;RIM1 ${ }^{-1-}$ mice breakpoints in PR schedule responding. Two-way mixed ANOVAs were used to assess main effects and interactions of genotype with repeated-measures variables (e.g., paired pulse ratios at multiple interpulse intervals in RIM fllfl or Emxl::Cre;RIM1 ${ }^{-1-}$ mice). Post hoc significance was determined using Sidak's multiplecomparisons test. A hierarchical linear mixed model was used to assess main effects and interactions of genotype with repeated-measures variables that contain nested variables (e.g., rotarod latencies across trials nested within days in $R I M 1^{f l / f l}$ and Emx1::Cre;RIM1 ${ }^{-1-}$ mice). All pair- wise comparisons of the model-derived estimated marginal means underwent Bonferroni corrections, and all reported $p$ values reflect these corrections. Sex differences were analyzed for each category of behavior using one-sample Student's $t$ tests and two-way ANOVAs, where appropriate. Effects were considered statistically significant at $p<0.05$. Data were analyzed using MiniAnalysis, Clampfit, Microsoft Excel, GraphPad Prism 6, and PASW Statistics 18.

\section{Results}

\section{Verification of conditional RIM1 KO}

To assess the efficacy of our conditional RIM1 deletion strategy, we performed qRT-PCR on brain samples from RIM1 $1^{f l f l}$ and Emx1::Cre;RIM1 ${ }^{-1-}$ mice. Consistent with the known expression patterns of Emx1::Cre mice (Gorski et al., 2002), RIM1 mRNA was reduced in motor cortex (M1 and M2) of Emx1::Cre; $R I M 1^{-1-}$ mice relative to RIM1 $1^{f l f l}$ littermates (Fig. $1 A ; n=4$, $\left.n=4 ; t_{(6)}=8.421, p<0.0005\right)$ but was indistinguishable from controls in dorsal striatum $\left(n=5, n=5 ; t_{(8)}=1.327, p=0.221\right)$ and thalamus $\left(n=4, n=5 ; t_{(7)}=0.986, p=0.357\right)$.

\section{Normal viability, brain and body weight, and gross brain} morphology in conditional RIM1 KO mice Emx1::Cre;RIM1 ${ }^{-1-}$ mice were viable and fertile. Offspring of Emx1::Cre;RIM1 ${ }^{-1-\times} R I M 1^{f l f l}$ were born at the expected Mendelian ratios (Fig. $1 B$ ), and survived normally into adulthood. Body and brain weights of Emx1::Cre;RIM1 ${ }^{-1-}$ mice did not 

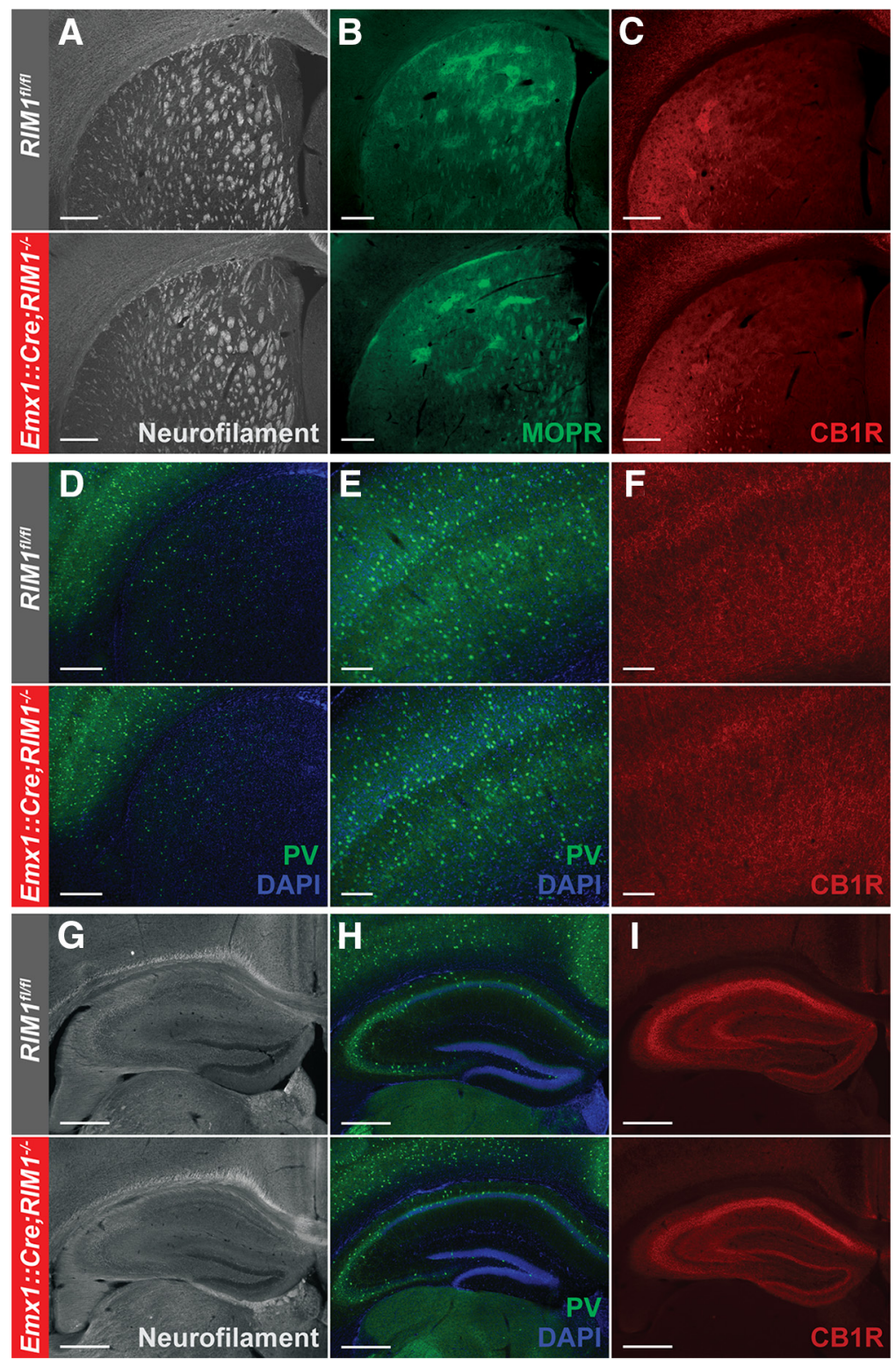

Figure 2. Gross brain anatomy is unaltered in conditional RIM1 K0 mice. $A-I$, Neurofilament, (B1R, mu opioid receptor (MOPR), parvalbumin (PV), and/or DAPI staining of striatum $(\boldsymbol{A}-\boldsymbol{D})$, motor cortex $(\boldsymbol{E}, \boldsymbol{F})$ and hippocampus $(\mathbf{G}-\boldsymbol{I})$ of $R I M 1^{f / / f l}$ and $E m \times 1:: C r e$; $R_{I M 1^{-I}}{ }^{-}$mice. Scale bars: $A-D, G-I, 400 \mu \mathrm{m} ; \boldsymbol{E}, \boldsymbol{F}, 200 \mu \mathrm{m}$.

differ from those of littermate RIM ${ }^{f l f l}$ controls (Fig. $1 C: n=14$, $n=16 ; t_{(28)}=0.766, p=0.45$; Fig. $1 D: n=7, n=8 ; t_{(13)}=1.17$, $p=0.263)$. Morphological analyses revealed no gross structural abnormalities in brain architecture in the conditional RIM1 KO mice. Notably, unlike mice with Emx1 promoter-driven conditional KO of the presynaptic CB1R (Davis et al., 2018), Emxl:: Cre;RIM1 ${ }^{-1-}$ mice showed normal axonal fasciculation of cortical fibers into and through striatum as revealed by immunostaining for neurofilament (Fig. 2A). Striatal CB1R and mu opioid receptor expression patterns were also normal in Emx1::Cre; $\mathrm{RIM1}^{-1-}$ mice (Fig. $2 \mathrm{~B}, \mathrm{C}$ ), indicating preserved striosomematrix striatal compartments in mice lacking cortical RIM1. Mesoscale cortical and hippocampal structure was similarly preserved in these mice, as indicated by labeling with DAPI and immunostaining for neurofilament, parvalbumin, and $\mathrm{CB} 1 \mathrm{R}$ (Fig. 2D-I).

\section{Impaired excitatory transmission at corticostriatal synapses in conditional RIM1 KO mice}

Given our interest in probing the role of corticostriatal RIM1 in action learning and control, we examined synaptic transmission and plasticity in the conditional RIM1 KO mice at cortical inputs to the DLS, a brain region widely implicated in the development and expression of habitual behaviors (Yin et al., 2004; Balleine et al., 2007). Furthermore, despite evidence of diverse, synapse-specific roles for RIM $1 \alpha$ in transmission and plasticity at several central projections (Castillo et al., 2002; Schoch et al., 2002; Chevaleyre et al., 2007; Kiyonaka et al., 2007; Fourcaudot et al., 2008; Kintscher et al., 2013), and detailed characterization of presynaptic forms of plasticity at cortical inputs to the DLS (Gerdeman et al., 2002; Mathur et al., 2011; Atwood et al., 2014), no studies to date have determined physiological roles for RIM1 at corticostriatal synapses in the DLS, or dorsal striatum more generally.

To assess the contribution of RIM1 to excitatory transmission in the DLS, we first examined spontaneous excitatory postsynaptic current (sEPSC) frequency, amplitude, and kinetics in DLS MSNs of Emx $1:: C r e ; R I M 1^{-1-}$ and RIM1 $1^{f l f l}$ mice. sEPSC frequency was significantly reduced in Emx1::Cre;RIM1 $1^{-1-}$ relative to RIM1 $^{f l f l}$ mice (Fig. $3 A ; n=15, n=15$, $\left.t_{(28)}=2.207, p<0.05\right)$. However, conditional deletion of RIM1 had no effect on sEPSC amplitude (Fig. $3 B ; t_{(28)}=1.624$, $p=0.116)$. sEPSC rise time, decay time, and total charge transfer were indistinguishable between the two groups (data not shown). These findings suggest that loss of RIM1 in cortical excitatory cells causes impaired glutamate release in the DLS.

To assess whether conditional RIM1 $\mathrm{KO}$ altered evoked neurotransmission, we measured EPSCs in DLS MSNs in response to electrical stimulation at the callosal-DLS border (Fig. 4A). Stimulation across a range of intensities revealed a significant reduction in evoked EPSC amplitude in Emx1::Cre;RIM1 ${ }^{-1-}$ mice relative to RIM1 $1^{f l f l}$ littermates (Fig. $4 B ; n=9, n=11$; two-way ANOVA: current $\times$ genotype interaction: $\left.F_{(10,180)}=2.557, p<0.01\right)$, indicative of an impairment in evoked excitatory transmission.

To test whether the changes in corticostriatal neurotransmission following RIM1 KO could be attributed to changes in presynaptic release probability, we assessed the ratio of excitatory synaptic responses to pairs of closely timed electrical pulses (paired pulse ratio) in DLS MSNs of Emx1::Cre;RIM1 ${ }^{-/-}$and $R I M 1^{f l f l l}$ mice. Paired pulse facilitation was enhanced in Emx1:: Cre;RIM1 ${ }^{-1-}$ mice relative to $R I M 1^{f l f l}$ littermates (Fig. $4 C ; n=$ $15, n=11$; genotype: $F_{(1,24)}=7.825, p<0.05$; IPI $\times$ genotype interaction: $\left.F_{(6,144)}=2.997, p<0.01\right)$, particularly at short in- 
terpulse intervals (20 ms, $p<0.001 ; 40 \mathrm{~ms}$, $p<0.05)$. Because paired pulse facilitation is normally inversely correlated with neurotransmitter release probability (Thomson, 2000), this finding suggests that transmitter release probability is lower at corticostriatal synapses lacking RIM1.

We also measured the adaptation of synaptic responses during short trains of moderate frequency stimulation (5-10 $\mathrm{Hz}$ ) to further assess how transmission and use-dependent short-term plasticity are impaired following conditional deletion of RIM1. RIM1 fl/fl and Emx1::Cre; $R I M 1^{-1-}$ mice showed no difference in the depression of EPSC amplitude observed across a $2 \mathrm{~s}, 5 \mathrm{~Hz}$ train (data not shown); however, relative to $R I M 1^{f l f l}$ mice, Emx1::Cre;RIM1 ${ }^{-1-}$ mice showed a resistance to the depression observed across a 2 s, $10 \mathrm{~Hz}$ train (Fig. $4 D ; n=13$, $n=12$; main effect of stimulus: $F_{(19,437)}=$ 34.50, $p<0.001$; main effect of genotype: $F_{(1,23)}=7.143, p<0.05$; stimulus $\times$ genotype interaction: $F_{(19,437)}=1.832, p<$ $0.05)$. These findings are further consistent with a use-dependent impairment in synaptic transmission at corticostriatal synapses.

Spared forms of short- and long-term plasticity at corticostriatal synapses in conditional RIM1 KO mice

To assess whether corticostriatal RIM1 was necessary for presynaptic GPCRmediated forms plasticity in the DLS (Lovinger, 2010), we first tested RIM1 $1^{f l / f l}$ and Emx1::Cre;RIM1 ${ }^{-1-}$ mice for DSE, an effect mediated by short-term endocannabinoid signaling at CB1Rs on striatal glutamatergic terminals (Shonesy et al., 2013). DSE was intact and of similar magnitude and duration in slices from conditional RIM1 $\mathrm{KO}$ and control mice (Fig. $5 A ; n=10, n=10$; unpaired $t$ test [on amplitude of first EPSC following depolarization]; $\left.t_{(18)}=0.154, p=0.880\right)$.

We then assessed whether endocannabinoid/CB1R-mediated LTD of excitatory transmission in the DLS, induced by treatment with DHPG (Kreitzer and Malenka, 2005), was intact in conditional RIM1 KO mice. RIM1 $1^{f l f l}$ and Emx1::Cre;RIM1 ${ }^{-/-}$mice showed comparable DHPG-induced LTD (Fig. $5 B ; n=7, n=8$; unpaired $t$ test [on average EPSC amplitude during final $10 \mathrm{~min}$ ]; $\left.t_{(13)}=1.212, p=0.247\right)$. Pretreatment with the CB1R antagonist, AM251, confirmed that DHPG-induced LTD in both groups of mice required activation of this presynaptic receptor (Fig. $5 C$; DHPG vs AM251+DHPG in Emx1::Cre;RIM1 ${ }^{-1-}$ mice; $n=6$, $n=8$; unpaired $t$ test [on average EPSC amplitude during final 10 $\min ] ; t_{(12)}=2.445, p<0.05 ;$ DHPG vs AM251+DHPG in $R I M 1^{f l f l l}$ mice; $n=7, n=7$; unpaired $t$ test; $t_{(12)}=1.278, p=$ 0.128; DHPG alone in RIM1 $1^{f l / f l}$ mice; $n=7$; one-sample $t$ test, against baseline of $100 ; t_{(6)}=4.148, p<0.001$; AM251+DHPG
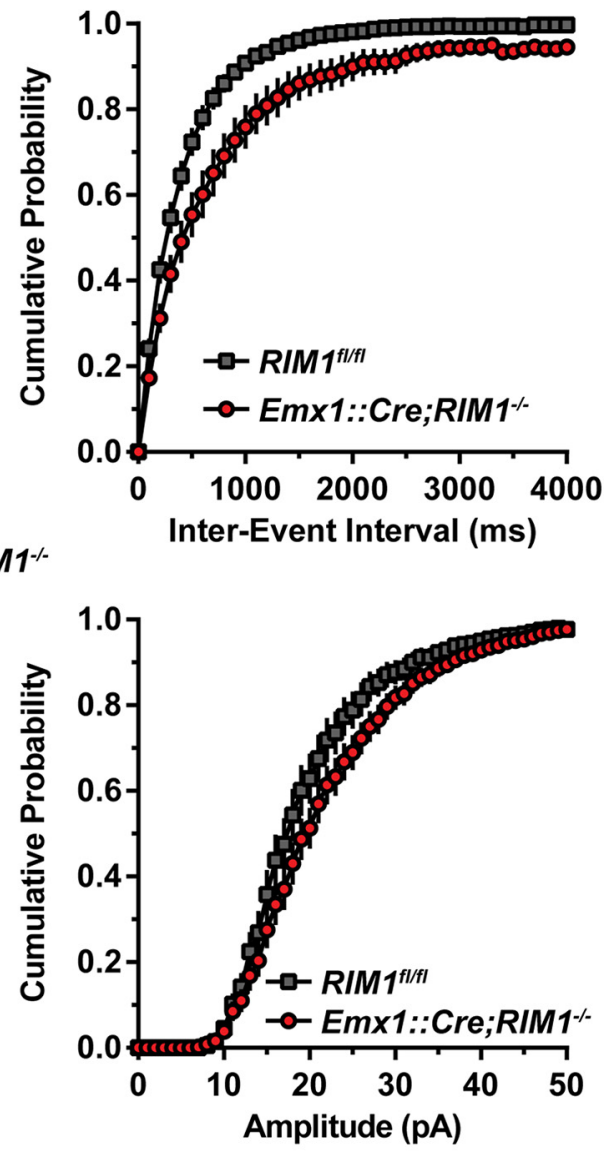

Amplitude (pA)

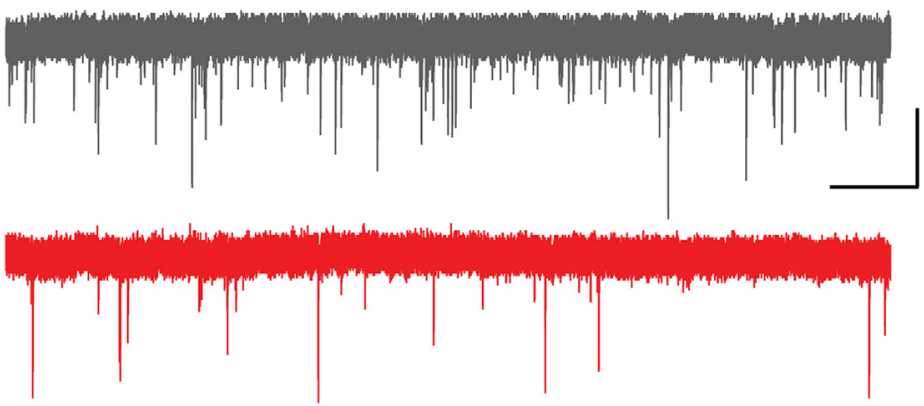

Figure 3. Impaired spontaneous excitatory synaptic transmission in DLS of conditional RIM1 K0 mice. A, Average and cumulative probability plots of frequency and interevent interval of sEPSCs in DLS of $R I M 1^{f / / f l}$ and Emx $1:: C r e ; R I M 1^{-1-}$ mice. $B$, Average and cumulative probability plots of amplitude of sEPSCs in DLS of $R I M 1^{f I / f l}$ and Emx $1:: C r e$; RIM1 ${ }^{-1-}$ mice. ${ }^{*} p<0.05$, different from $R I M 1^{f l / f l}$ group. Calibration: 2 s, $20 \mathrm{pA}$.

in $R I M 1^{f l f l}$ mice; $n=7$; one-sample $t$ test; $t_{(6)}=1.217, p=0.269$ ). Demonstrating that the lack of effect of conditional RIM1 deletion on long-term forms of plasticity extended beyond LTD mediated through CB1Rs, we found that LTD induced by the $\mathrm{mGlu}_{2 / 3}$ receptor agonist LY379268 was indistinguishable in $R I M 1^{f l / f l}$ and Emxl::Cre;RIM1 ${ }^{-1-}$ mice (Fig. $5 D ; n=4, n=7$; unpaired $t$ test [on average EPSC amplitude during final $10 \mathrm{~min}$ ]; $\left.t_{(9)}=1.181, p=0.268\right)$. Together, these findings indicate that RIM1 within cortical inputs to the DLS is necessary for normal corticostriatal transmission, but not for several forms of shortand long-term presynaptic plasticity.

Transiently enhanced homecage locomotion in conditional RIM1 KO mice

Given this synaptic phenotype in a brain region critical for action learning and control, we next evaluated conditional RIM1 KO 
A

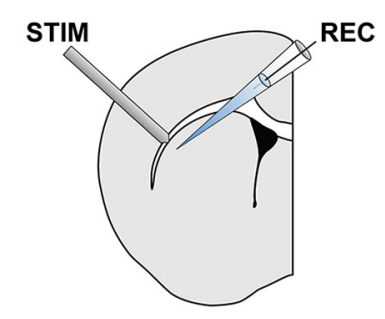

C
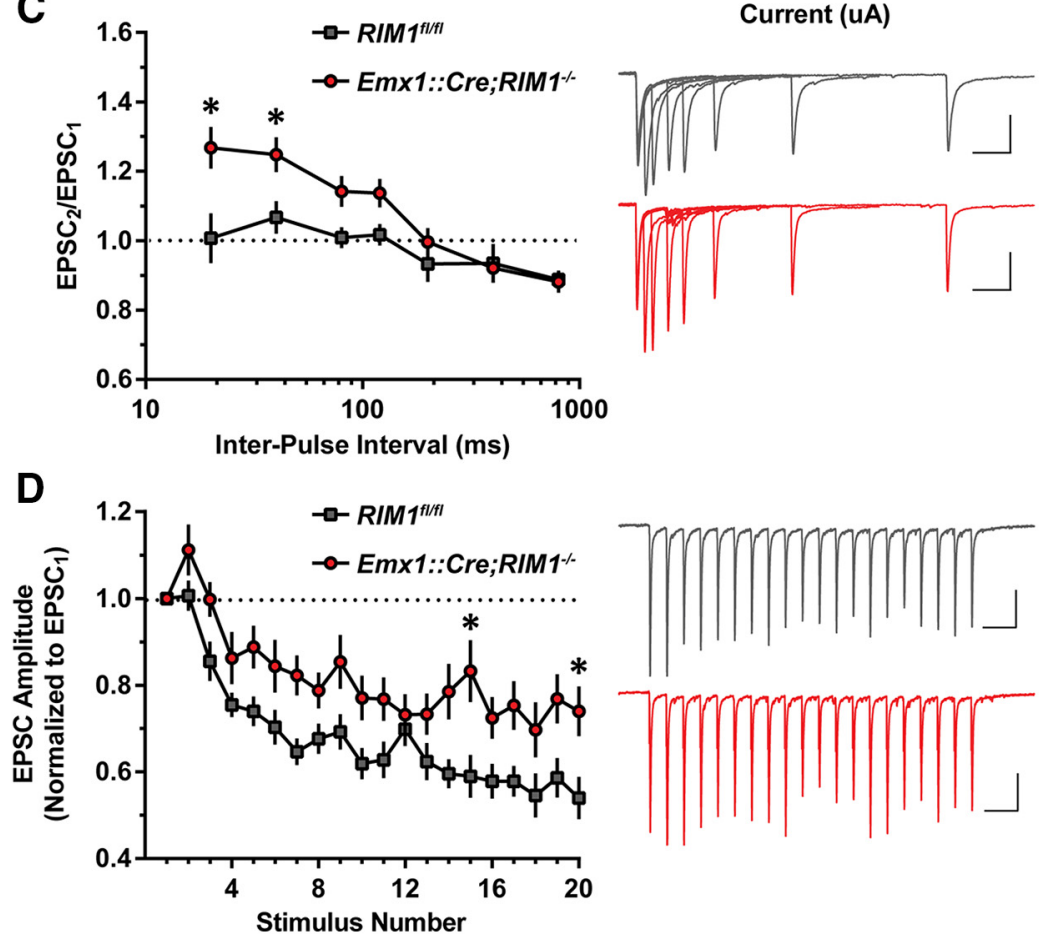

Figure 4. Impaired evoked excitatory synaptic transmission in DLS of conditional RIM1 KO mice. $\boldsymbol{A}$, Schematic diagram of stimulating and recording electrode placement in DLS. $\boldsymbol{B}$, Input- output curves of electrically evoked excitatory currents in DLS of $R I M 1^{f / f f l}$ and $E m \times 1::\left(r e ; R I M 1^{-1-}\right.$ mice. C, Paired pulse ratios of electrically evoked excitatory transmission in DLS of $R I M 7^{f / / f l}$ and Emx1::Cre;RIM1 ${ }^{-1-}$ mice. D, Activity-dependent depression during $10 \mathrm{~Hz}$ train of electrical stimulation at border of DLS in

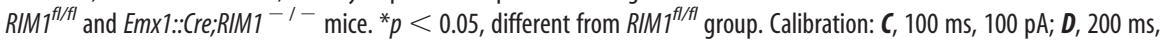
$100 \mathrm{pA}$.

mice for associated behavioral deficits. RIM1 ${ }^{f l f l}$ and Emxl::Cre; $\mathrm{RIM1}^{-/-}$mice were first assessed for differences in basal locomotion in their homecages for $24 \mathrm{~h} / \mathrm{d}$ for $3 \mathrm{~d}$. Mice were placed into a homecage with fresh bedding $1 \mathrm{~h}$ into the dark period. Emx1::Cre;RIM1 ${ }^{-1-}$ mice showed enhanced locomotion during the first dark period relative to their RIM $1{ }^{\mathrm{fl} / \mathrm{fl}}$ littermates, but this diminished to control levels by the first light period (Fig. $6 A-C$; $n=8, n=13$; hierarchical linear mixed model; main effect of day: $F_{(2,95)}=29.153, p<0.001$; main effect of genotype: $F_{(1,19)}=$ $1.302, p=0.268$; light $\times$ day interaction: $F_{(3,95)}=105.721, p<$ 0.0001 ; day $\times$ genotype interaction: $F_{(2,95)}=1.306, p=0.276$; light $\times$ day $\times$ genotype interaction: $F_{(3,95)}=3.701, p=0.014$; day 1, dark, RIM1 $1^{f l f l}$ vs Emx1::Cre;RIM1 $\left.{ }^{-1-}, p<0.01\right)$.

Novelty-induced hyperactivity in conditional RIM1 KO mice To further characterize this hyperactivity phenotype, Emx1::Cre; $R I M 1^{-/-}$and $R I M 1^{f l / f l}$ mice were tested for locomotion during the light period in a novel cage for $2 \mathrm{~h} / \mathrm{d}$ for $6 \mathrm{~d}$. One cohort of mice had their testing cages replaced with a clean cage daily, and a different cohort had their cages left unchanged for the $6 \mathrm{~d}$ period. Emx1::Cre; RIM1 ${ }^{-1-}$ mice whose cages were changed daily showed enhanced locomotion on day 1 that gradually converged with levels seen in $R I M 1^{f l f l}$ littermate controls by day 4 (Fig. $6 D, E ; n=11, n=12$; two-way ANOVA; main effect of genotype: $F_{(1,21)}=6.976, p<0.05$; day $\times$ genotype interaction: $F_{(5,105)}=8.130, p<$ 0.001; RIM1 $1^{f l / f l}$ vs Emx1::Cre;RIM1 ${ }^{-/-}$, day 1: $p<0.001$; day 2: $p<0.05$; day 3: $p<0.05)$. Importantly, these locomotor effects were not driven by Cre expression alone because Emx1::Cre mice showed normal locomotion in a novel cage (Fig. $6 F ; n=9, n=9$; two-way ANOVA; main effect of genotype: $F_{(1,16)}=0.011, p=$ 0.919). Emx1::Cre;RIM1 ${ }^{-1-}$ mice whose cages were left unchanged showed initially enhanced locomotion that reduced to control levels by day 2 (Fig. $6 G, H ; n=10$, $n=11$; two-way ANOVA; main effect of genotype: $F_{(1,19)}=0.863, p=0.365$; day $\times$ genotype interaction: $F_{(5,95)}=$ 9.086, $p<0.001$; RIM1 ${ }^{f l f l}$ vs Emx1::Cre; $R I M 1^{-1-}$, day 1: $\left.p<0.05\right)$. Together, these findings suggest that Emx1::Cre; $R I M 1^{-1-}$ mice show novelty-induced hyperactivity.

To assess sex differences in this hyperactivity, we combined data collected on locomotor test day 1 from both experimental cohorts (those whose cages were subsequently changed or unchanged). Male and female Emx1::Cre;RIM1 ${ }^{-1-}$ mice showed comparable noveltyinduced hyperactivity relative to their $R I M 1^{f l f l}$ littermates (males, $n=11, n=$ 10; females, $n=10, n=13$; two-way ANOVA; main effect of sex: $F_{(1,40)}=1.21$, $p=0.278$; main effect of genotype: $F_{(1,40)}$ $=20.57, p<0.0001$; sex $\times$ genotype interaction: $\left.F_{(1,40)}=2.841, p=0.10\right)$. The novelty-induced hyperactivity seen here parallels that seen in global RIM1 $\alpha \mathrm{KO}$ mice (Blundell et al., 2010) and mice with conditional RIM1 KO driven by the kainate receptor subunit 1 promoter (Haws et al., 2012). Notably, Emx1::Cre;RIM1 ${ }^{-1-}$ mice did not recapitulate every phenotype seen in global RIM $1 \alpha$ $\mathrm{KO}$ mice, including impairments in prepulse inhibition (Fig. 6I; $n=10, n=10$; two-way ANOVA; main effect of genotype: $F_{(1,18)}=0.079, p=0.781$ ) (Blundell et al., 2010).

Impaired motor skill learning in conditional RIM1 KO mice In a further phenotypic departure from global RIM1 $\alpha$ mice (Powell et al., 2004), Emx1::Cre;RIM1 ${ }^{-1-}$ mice showed impaired performance on the accelerating rotarod relative to their $R I M 1^{f l / f l}$ littermates (Fig. $7 ; n=16, n=15$; hierarchical linear mixed model; main effect of day: $F_{(3,319)}=39.759, p<0.0001$; main effect of genotype: $F_{(1,29)}=4.411, p<0.05$; trial $\times$ day interaction, $\left.F_{(8,319)}=12.067, p<0.0001\right)$. Male and female Emx1::Cre; RIM1 $^{-1-}$ mice showed comparable deficits in overall rotarod performance relative to their $R I M 1^{f l f l}$ littermates (males, $n=10$, 

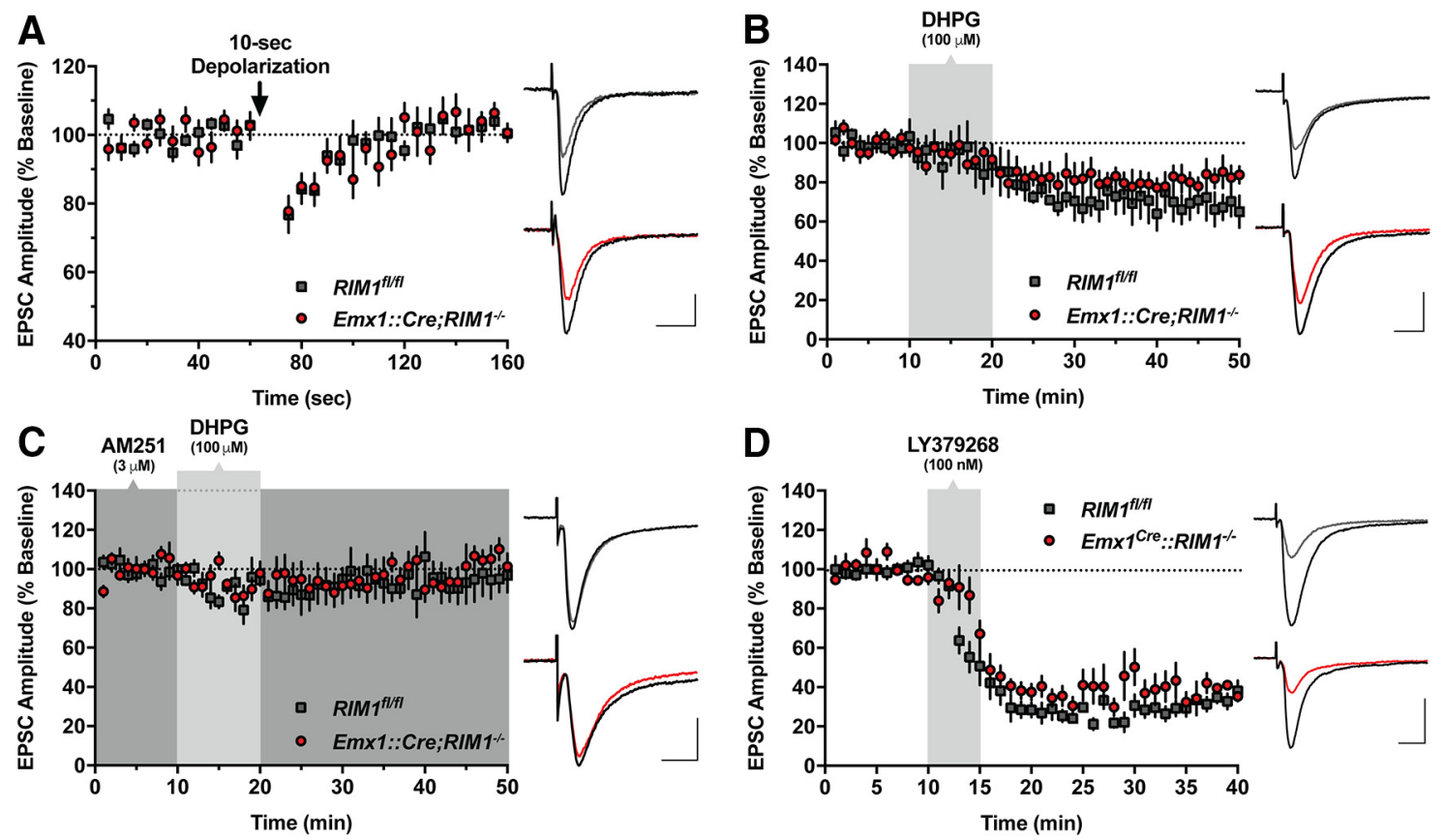

Figure 5. Intact short- and long-term depression of excitatory synaptic transmission in conditional RIM1 KO mice. A, DSE in DLS of $R I M 1^{f / / f l}$ and Emx1::Cre;RIM1 ${ }^{-1-}$ mice. Arrow indicates $10 \mathrm{~s}$ period of postsynaptic depolarization to $0 \mathrm{mV}$. B, DHPG-induced LTD of EPSCs in DLS of $R I M 7^{f / f / f}$ and Emx1::Cre;RIM1 ${ }^{-1}{ }^{-}$- mice. C, Effects of CB1Rantagonist AM251 preincubation on DHPG-mediated

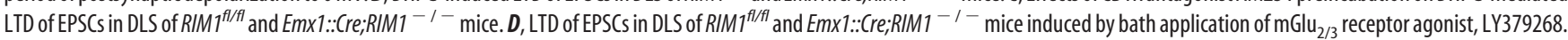
Calibration: $10 \mathrm{~ms}, 100 \mathrm{pA}$.
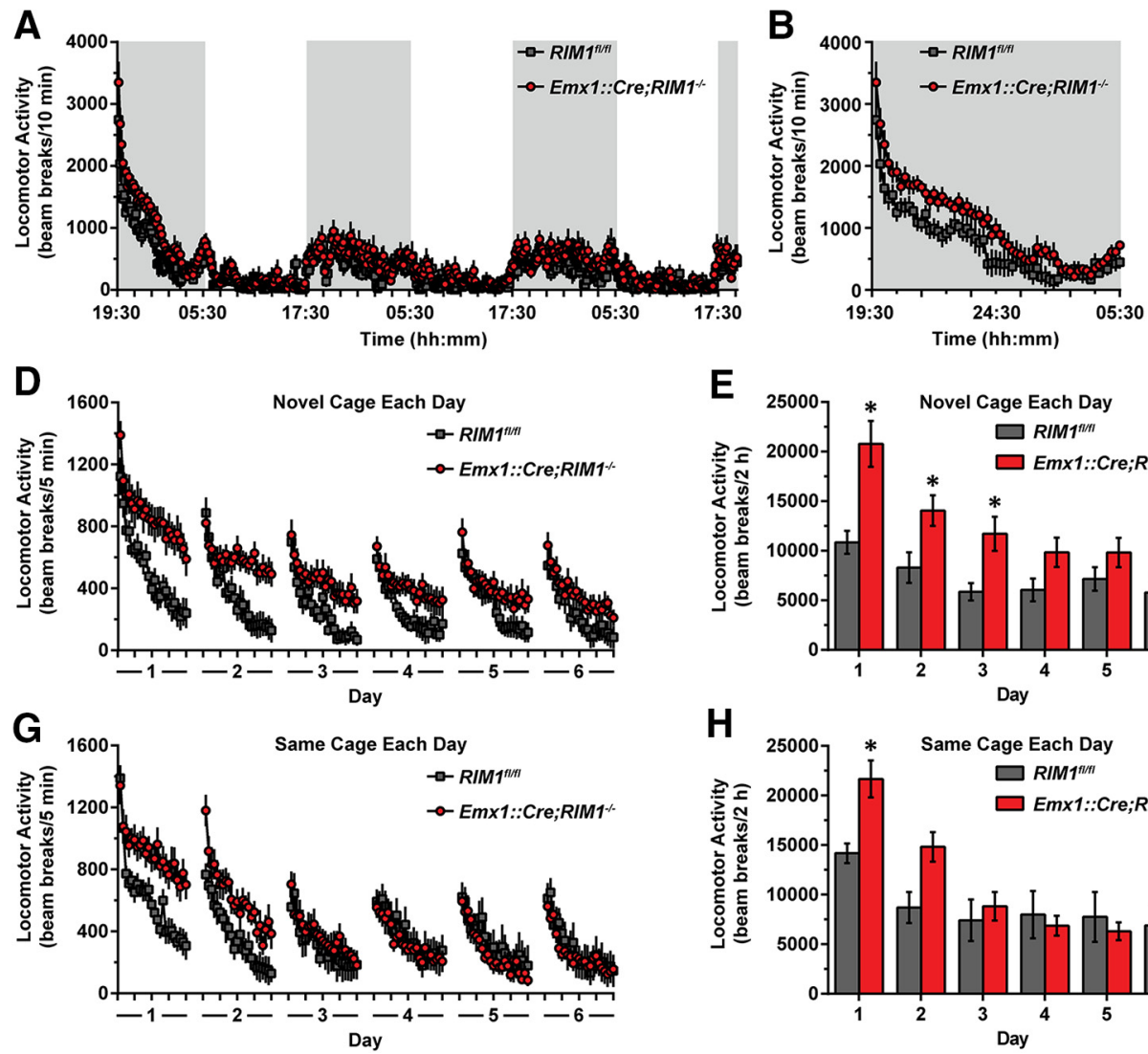

E
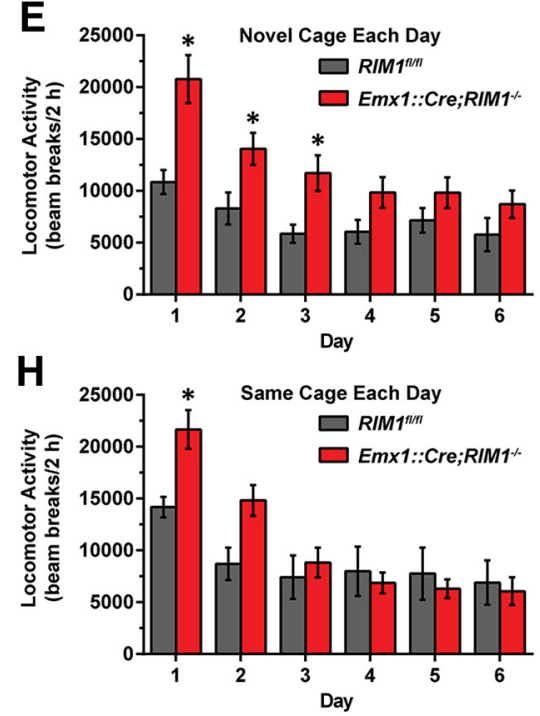

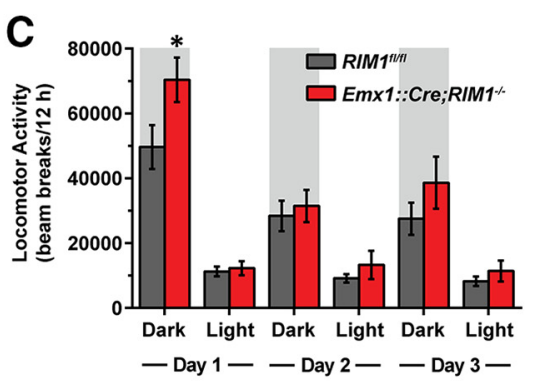

F

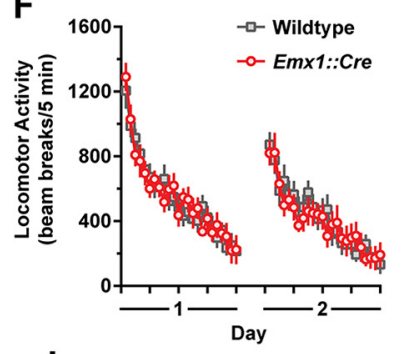

I

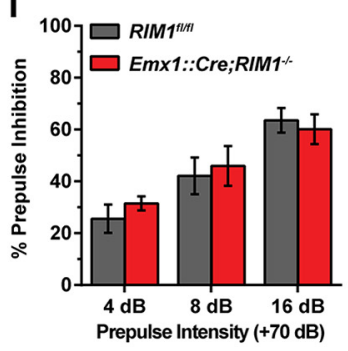

Figure 6. Enhanced novelty-induced locomotion in conditional RIM1 K0 mice. A-C, Homecage locomotion in $R I M 1^{f / f f l}$ and Emx $1:: C r e ; R I M 1^{-1-}$ across $3 \mathrm{~d}$. Novelty-induced locomotion was observed in the first $10 \mathrm{~h}$ following exposure to the novel homecage $(\boldsymbol{B})$. $\boldsymbol{D}, \boldsymbol{E}$, Novelty-induced locomotion in $R I M 7^{f / f l}$ and $E m x 1:: C r e: R I M 1^{-l-}$ mice in $10 \mathrm{~min}(\boldsymbol{D})$ or $120 \mathrm{~min}$ bins $(\boldsymbol{E})$ when fresh bedding and a new locomotor chamber were introduced daily. $\boldsymbol{F}$, No novelty-induced hyperactivity was observed in Emx 1::Cre mice. $\mathbf{G}, \boldsymbol{H}$, Novelty-induced locomotion in $R I M 7^{f l / f l}$ and $E m \times 1::(r e$; $R I M 1^{-1-}$ mice in $10 \mathrm{~min}(\boldsymbol{G})$ or 120 min bins $(\boldsymbol{H})$ when cages were unchanged across 6 d of locomotor testing. ${ }^{*} p<0.05$, different from $R I M 7^{f / / f l}$ group. $I$, Prepulse inhibition in $R I M 7^{f l / f l}$ and Emx1::Cre;RIM1 ${ }^{-1-}$ mice. 


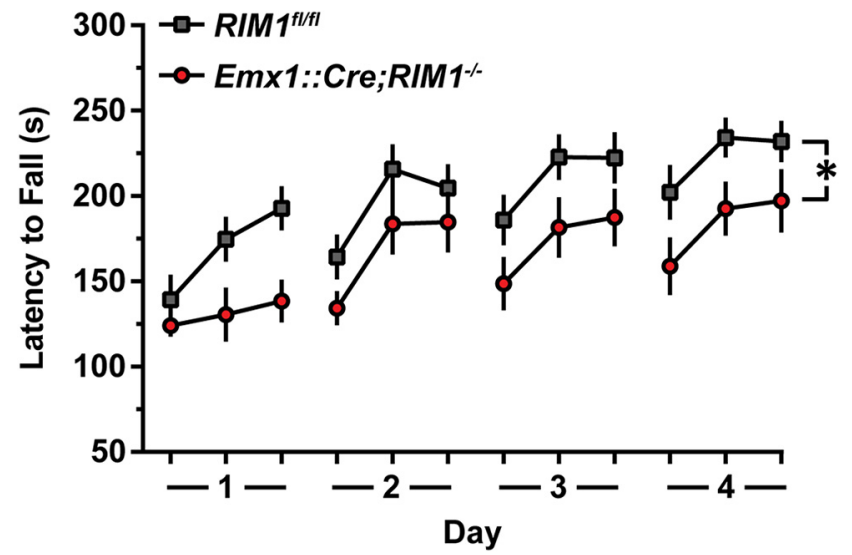

Figure 7. Impaired motor learning in conditional RIM1 KO mice. Latency to fall from the accelerating rotarod in $R I M 7^{f / f t}$ and Emx1::Cre;RIM1 ${ }^{-1-}$ mice. ${ }^{*} p<0.05$, different from $R I M 1^{f / / f l}$ group.

$n=10$; females, $n=6, n=5$; two-way ANOVA; main effect of sex: $F_{(1,27)}=2.616, p=0.117$; main effect of genotype: $F_{(1,27)}=$ 4.617, $p<0.05$; sex $\times$ genotype interaction: $F_{(1,27)}=0.3521, p=$ $0.558)$. These findings suggest that cortical RIM1 may be particularly important for aspects of action learning, including the refinement of actions into motor skills.

\section{Heightened responding on FR and PR schedules in conditional RIM1 KO mice}

We next assessed whether RIM1-dependent processes in forebrain excitatory neurons were required for normal instrumental learning. RIM1 $1^{f l f l}$ and Emx1::Cre;RIM1 ${ }^{-/-}$mice were food restricted and trained to lever press for food pellets on escalating FR schedules of reinforcement. Both groups pressed the "active" lever sufficient numbers of times to receive all allotted food pellets each day (Fig. 8A). However, Emx1::Cre;RIM1 ${ }^{-1-}$ mice showed heightened rates of responding for food during the higher FR sessions (Fig. $8 B ; n=14, n=12$; two-way ANOVA; main effect of genotype: $F_{(1,24)}=6.063, p<0.05$; day $\times$ genotype interaction: $F_{(8,192)}=4.519, p<0.001 ; R I M 1^{f l / f l}$ vs Emx1::Cre;RIM1 ${ }^{-/-}$, day 8 and 9: $p<0.05)$. Emx1::Cre;RIM1 $1^{-/-}$mice also showed temporarily heightened numbers of head entries into the food dispenser early in instrumental training (Fig. $8 C$; $n=11, n=11$; two-way ANOVA; day $\times$ genotype interaction: $F_{(8,160)}=2.076$, $p<0.05 ; R I M 1^{f l f l}$ vs Emxl::Cre;RIM1 ${ }^{-1-}$, day $\left.2: p<0.05\right)$. These behavioral differences were not attributable to differences in body weight responses to food restriction (Fig. 8D) or to general differences in propensity for consumption, as $R I M 1^{f l / f l}$ and Emx1::Cre;RIM1 ${ }^{-1-}$ mice ate comparable amounts of food during subsequent post testing ad libitum access to food pellets in their homecages $\left(R I M 1^{f l f l}, 6.27 \pm 0.34 \mathrm{~g}\right.$ vs Emx1::Cre;RIM1 ${ }^{-1-}$, $6.66 \pm 0.23 \mathrm{~g}$ ). Heightened responding also did not simply reflect general hyperactivity as average daily inactive lever pressing rates were statistically indistinguishable across groups (two-way ANOVA; main effect of genotype: $\left.F_{(1,24)}=0.882, p=0.357\right)$ and press counts were consistently low across all training sessions $\left(R I M 1^{f l f l}, 5.18 \pm 1.50\right.$ presses vs Emx1::Cre;RIM1 ${ }^{-/-}, 7.31 \pm$ 1.83 presses).

Mice subsequently underwent a PR test in which they were required to press the active lever a progressively increasing number of times to receive a food pellet. Relative to littermate $R I M 1^{f l / f l}$ controls, Emx1::Cre;RIM1 ${ }^{-1-}$ mice showed heightened active lever pressing for food during this test (Fig. 8E; unpaired $t$ test; $\left.t_{(24)}=3.295, p<0.005\right)$, and obtained higher breakpoints in their responding (Fig. 8F; Mann-Whitney test; $U=26, p<$ 0.005). Male and female Emx1::Cre;RIM1 ${ }^{-1-}$ mice showed comparably enhanced active lever pressing during the PR test relative to their RIM1 ${ }^{f l f l}$ littermates (males, $n=7, n=8$; females, $n=5$, $n=6$; two-way ANOVA; main effect of sex: $F_{(1,22)}=1.13, p=$ 0.299; main effect of genotype: $F_{(1,22)}=6.505, p<0.05$; sex $\times$ genotype interaction: $\left.F_{(1,22)}=0.020, p=0.888\right)$. Responding on the inactive lever during the PR test was also elevated in Emx1:: Cre;RIM1 ${ }^{-1-}$ relative to $R I M 1^{f l f l}$ mice $\left(t_{(24)}=2.703, p<0.05\right)$, but inactive lever responding was consistently low relative to active lever responding in both groups $(8.06 \pm 3.53 \%$ and $8.67 \pm$ $1.38 \%$ in $R I M 1^{f l f l}$ and Emxl::Cre;RIM1 ${ }^{-1-}$ mice, respectively). These results indicate that conditional RIM1 KO mice show heightened instrumental responding for food, most prominently under higher-effort conditions.

\section{Enhanced responding on RI schedules and resistance to developing habitual actions in conditional RIM1 KO mice} Action strategies used during instrumental learning and responding have been shown to exist on a gradient between outcome-dependent/goal-directed and outcome-independent/ habitual. To delineate the action strategy used by Emx1::Cre; $R I M 1^{-1-}$ mice during food responding, we trained a cohort of Emx1::Cre;RIM1 ${ }^{-1-}$ and RIM1 $1^{\text {flfl }}$ mice on escalating RI schedules of reinforcement known to bias learning toward the use of habitual response strategies (Dickinson, 1985; Gremel and Costa, 2013). RI schedules promote habitual responding by weakening the contingency and contiguity between the action (lever press) and outcome (food pellet) (Dickinson, 1985; Derusso et al., 2010). To assess their propensity to use a goal-directed or habitual action strategy, mice underwent sensory-specific satiety outcome devaluation testing over two consecutive days, termed valued and devalued days. Mice were permitted $1 \mathrm{~h}$ ad libitum consumption of either a familiar sucrose solution on the "valued" day, and food pellets previously earned by lever pressing on the "devalued" day, each followed by a 5 min period of nonrewarded lever pressing. A larger reduction in lever pressing in the devalued versus the valued state is indicative of greater goal-directed action control; indistinguishable lever pressing in the devalued and valued states is indicative of habitual control (Dickinson, 1985; Gremel et al., 2016).

Relative to $R I M 1^{f l f l}$ mice, Emx1::Cre;RIM1 ${ }^{-1-}$ mice showed heightened levels of responding (Fig. $9 A ; n=16, n=14$; two-way ANOVA; day $\times$ genotype interaction: $F_{(9,252)}=2.726, p<0.005$; $R I M 1^{f l f l}$ vs Emxl::Cre;RIM1 ${ }^{-1-}$, day 9 and 10, $\left.p<0.05\right)$ and rates of responding for food during high RI training (Fig. 9B; day $\times$ genotype interaction: $F_{(9,252)}=2.787, p<0.005 ; R I M 1^{f l f l}$ vs Emx1::Cre;RIM1 ${ }^{-1-}$, day $\left.10, p<0.05\right)$. As seen in the cohort of mice trained on escalating FR schedules, Emx1::Cre;RIM1 ${ }^{-1-}$ mice showed transiently elevated numbers of head entries early in instrumental training (Fig. 9C; $n=15, n=10$; two-way ANOVA; day $\times$ genotype interaction: $F_{(9,207)}=2.016, p<0.05 ; R I M 1^{f l f l}$ vs Emx1::Cre;RIM1 ${ }^{-1-}$, day 1: $p^{<0.05)}$. Again, this heightened responding was not attributable to genotype differences in body weight responses to food restriction (data not shown).

Devaluation testing revealed that $R I M 1^{f l / f l}$ mice responded comparably on the valued and devalued days (Fig. 9D; two-way ANOVA; valuation $\times$ genotype interaction: $F_{(1,28)}=5.862, p<$ 0.05 ; valued vs devalued, $\left.R I M 1^{f / f}: p=0.428\right)$, consistent with the expected use of a habitual action strategy following RI schedule training. In contrast, Emx $1:: C r e ; R I M 1^{-1-}$ mice showed reduced lever pressing on the devalued day relative to the valued day (Fig. 
A

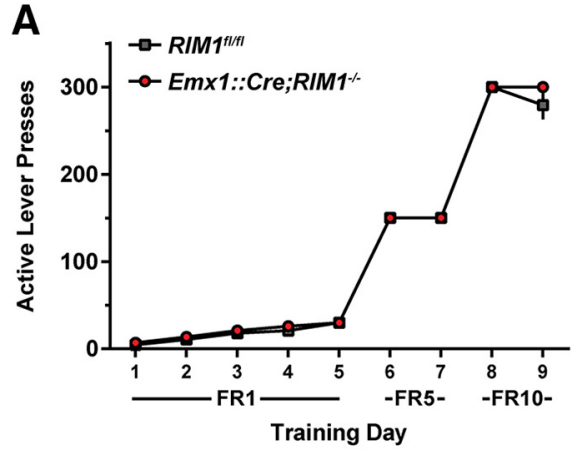

D

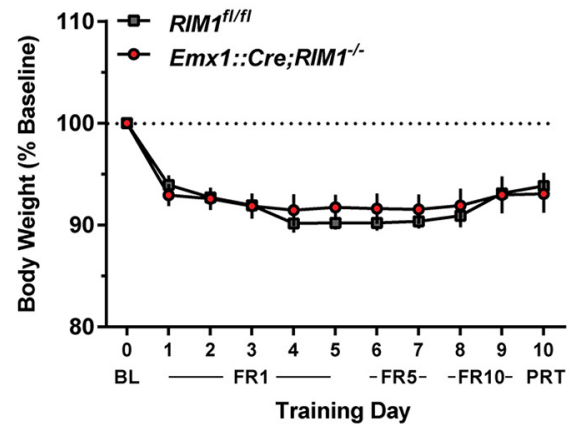

B

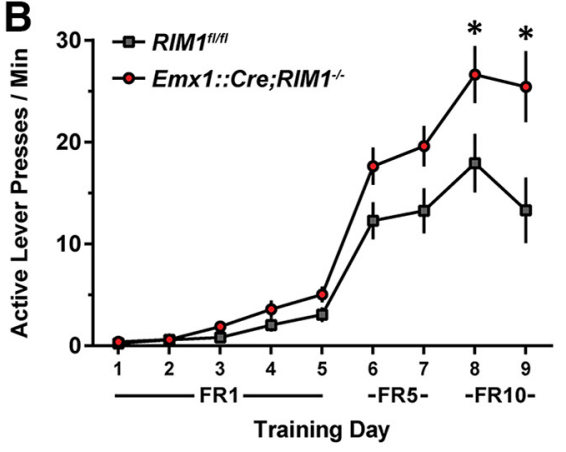

E

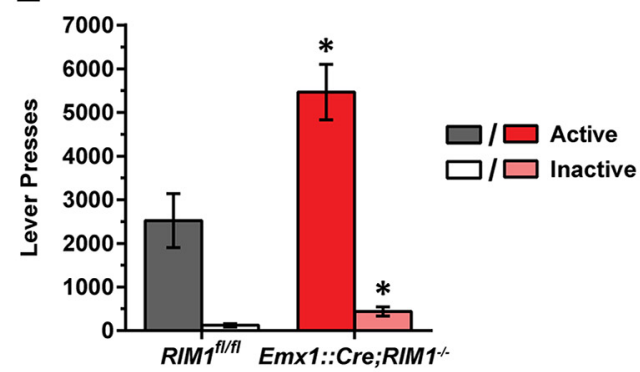

C

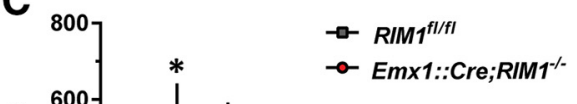

Figure 8. Enhanced instrumental responding for food in conditional RIM1 K0 mice. $\boldsymbol{A}, \boldsymbol{B}$, Active lever presses $(\boldsymbol{A})$, active lever presses/min $(\boldsymbol{B})$, and head entries into the food receptacle $(\boldsymbol{C})$ during FR schedule training in $R I M 1^{f / f t}$ and $E m \times 1::\left(r e ; R I M 1^{-1-}\right.$ mice. $\boldsymbol{D}$, Body weight response to food restriction across training. $\boldsymbol{E}, \boldsymbol{F}$, Active and inactive lever presses $(\boldsymbol{E})$ and breakpoints achieved $(\boldsymbol{F})$ during PR testing in $R I M 1^{f / / f l}$ and $E m x 1:: C r e ; R I M 1^{-1-}$ mice. ${ }^{*} p<0.05$, different from $R I M 1^{f / / f l}$ group.

A

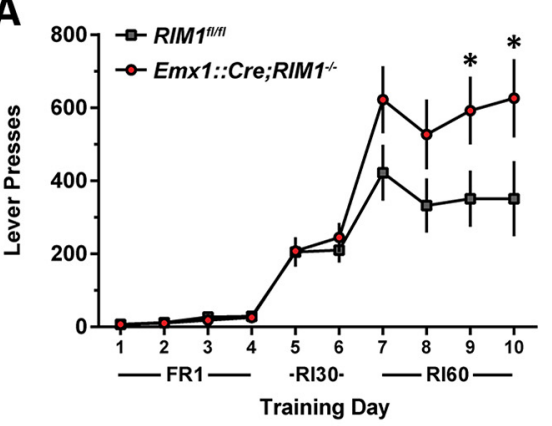

B
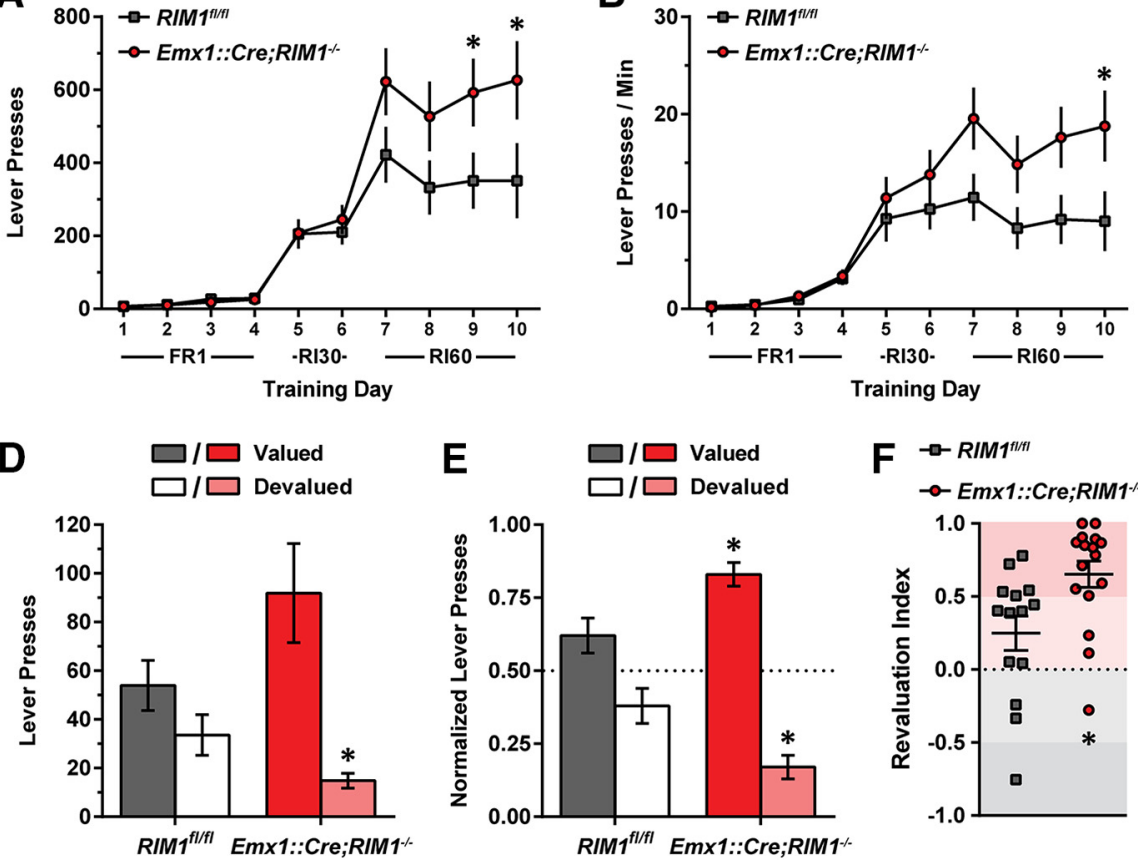

E $\square / \square$ Valued

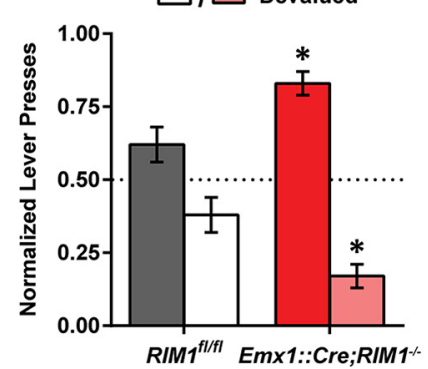

F $\rightarrow-R^{-2 M M^{m i n}}$

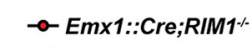

C

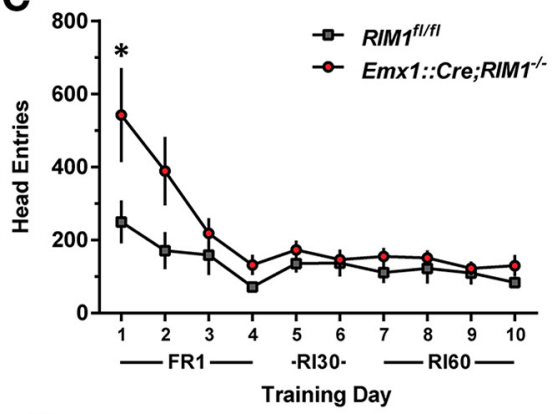

G

F

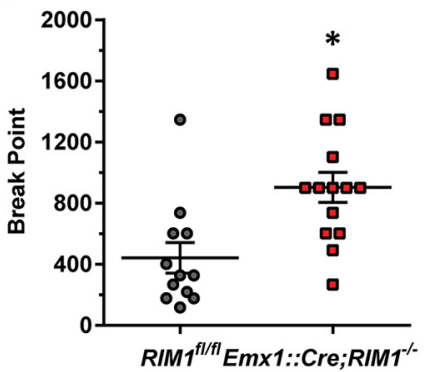

Figure 9. Impaired habitual responding for food in conditional RIM1 KO mice. $\boldsymbol{A}, \boldsymbol{B}$, Lever presses $(\boldsymbol{A})$, lever presses $/ \mathrm{min}(\boldsymbol{B})$, and head entries into the food receptacle $(\boldsymbol{C})$ during $\mathrm{FR}$ and $\mathrm{RI}$ schedule training in $R I M 1^{f / f f}$ and $E m \times 1:: C r e ; R I M 1^{-1-}$ mice. $\boldsymbol{D}$, Lever presses during valuation testing in $R I M 1^{f / f l}$ and $E m \times 1:: C r e ; R I M 1^{-1-}$ mice. ${ }^{*} p<0.05$, different from valued condition. $\boldsymbol{E}$, Normalized lever presses during valuation testing in $R I M 1^{f / / f l}$ and $E m \times 1:: C r e ; R I M 1^{-1-}$ mice. ${ }^{*} p<0.05$, different from $0.50 . \boldsymbol{F}$, Revaluation index in response to valuation testing in $R I M 1^{f / f f}$ and $E m \times 1:: C r e$;

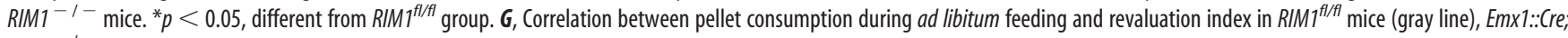
$R I M 1^{-1-}$ mice (red line), and both combined (black line). All correlations were nonsignificant.

9D; ANOVA [as above]; valued vs devalued, Emxl::Cre; $\left.R I M 1^{-1-}: p<0.05\right)$. Analysis of normalized lever pressing during valued and devalued conditions revealed that Emx1::Cre; $R I M 1^{-1-}$, but not $R I M 1^{f l / f l}$, mice were significantly sensitive to devaluation (Fig. 9E; one-sample $t$ test, against "no devaluation" point of 0.5 ; Emx1::Cre;RIM1 ${ }^{-1-}: t_{(15)}=7.293, p<0.0001$; RIM1 $\left.^{f l / f l}: t_{(13)}=2.119, p=0.054\right)$. Notably, devaluation in $R I M 1^{f l f l}$ mice narrowly avoided significance, indicative of mod- 
est expression of a habitual action strategy in these mice. Significant sensitivity to devaluation was seen in male and female Emx1::Cre;RIM1 ${ }^{-1-}$ mice (males, $n=7: t_{(6)}=7.901, p<$ 0.0005; females, $\left.n=9: t_{(8)}=4.136, p<0.005\right)$, but not male and female $R I M 1^{f l / f l}$ mice (males, $n=6: t_{(5)}=2.175, p=0.082$; females, $\left.n=8: t_{(7)}=1.077, p=0.317\right)$. Furthermore, using a "revaluation index" ([Valued - Devalued Lever Presses]/Total Lever Presses) as a measure of goal-directness (Gremel and Costa, 2013; Gremel et al., 2016), we found that Emx1::Cre;RIM1 ${ }^{-1-}$ mice showed greater goal-directedness than their $R I M 1^{f l f l}$ littermates (Fig. 9F; $t_{(28)}=2.774, p<0.01$ ). Notably, despite consuming comparable amounts of sucrose as RIM ${ }^{f l / f l}$ mice during the $1 \mathrm{~h}$ ad libitum feeding session preceding valuation testing $\left(0.92 \pm 0.16\right.$ vs $\left.0.79 \pm 0.13 \mathrm{~g}, t_{(28)}=0.612, p=0.546\right), E m \times 1::$ Cre;RIM1 ${ }^{-1-}$ mice consumed more food pellets than $R I M 1^{f l / f l}$ mice during the corresponding prefeeding session $(0.69 \pm 0.10 \mathrm{vs}$ $\left.0.40 \pm 0.06 \mathrm{~g}, t_{(28)}=2.459, p=0.020\right)$. However, no correlation was observed between pellet consumption and revaluation index in either group of mice (Fig. 9G), suggesting that variation in pellet consumption did not meaningfully impact devaluation of responding for pellets. Together, these data indicate that RIM1dependent processes in cortical excitatory neurons may help to constrain goal-directed action and contribute to the learning and/or use of habits.

\section{Discussion}

Here we combine genetic, electrophysiological, and behavioral approaches to assess presynaptic processes within corticostriatal projections that subserve normal action learning and control. We show that conditional deletion of RIM1 presynaptic scaffold proteins from corticostriatal projection neurons (and other forebrain excitatory neurons) impairs excitatory transmission in the DLS but spares many forms of presynaptic GPCR-mediated short- and long-term striatal plasticity. Conditional RIM1 KO mice show elevated locomotor responses to novelty and impaired motor learning on the accelerating rotarod. They further show abnormally robust goal-directed responding for food. These findings implicate RIM1-dependent processes in corticostriatal transmission and in the learning and control of motivated behavior.

The selective effect of RIM1 deletion on corticostriatal transmission (not CB1R- or $\mathrm{mGlu}_{2 / 3}$ receptor-mediated plasticity), although unexpected, is consistent with selective roles for RIM1dependent processes in transmission or plasticity at other central synapses (Castillo et al., 2002; Schoch et al., 2002; Lonart et al., 2003; Abrahamsson et al., 2017). Global deletion of RIM1 $\alpha$ has been shown to attenuate DHPG-induced LTD of excitatory transmission in the nucleus accumbens (Grueter et al., 2010); however, unlike in the present study, the terminal population driving the effect of this single isoform deletion is unclear. Furthermore, plasticity mechanisms are well documented to be differentiable in dorsal and ventral striatum subregions (Lovinger, 2010; Russo et al., 2010). Although it is possible that the lack of effect of RIM1 deletion on GPCR-mediated forms of plasticity resulted from recruitment of DLS inputs derived from populations of non-Emx1::Cre (and therefore RIM1-expressing) neurons, we believe this interpretation to be unlikely. First, Cre expression in Emx $1:$ Cre mice drives recombination in the vast majority $(\sim 88 \%)$ of cortical pyramidal neurons (Gorski et al., 2002). Indeed, we observed robust Cre-mediated knockdown of RIM1 mRNA in M1 and M2 motor cortices that densely innervate the DLS (Fig. 1A). Second, the other principle source of excitatory inputs to the DLS is the thalamus (Hunnicutt et al.,
2014, 2016), but the synaptic properties (e.g., paired pulse ratios) of the mixed striatal inputs stimulated in the present study more closely mimicked those of cortical rather than thalamic origin (Ding et al., 2008). Moreover, thalamostriatal inputs exhibit minimal CB1R expression and CB1R-mediated forms of plasticity (Wu et al., 2015; for $\mathrm{mGlu}_{2}$ receptor-mediated thalamostriatal plasticity, see Johnson et al., 2017). Therefore, effects of RIM1 deletion on presynaptic GPCR-mediated forms of corticostriatal plasticity are unlikely to be blunted by recruitment of RIM1expressing DLS inputs.

Conditional RIM1 deletion from cortical pyramidal neurons favored, and intensified, the use of goal-directed action strategies during instrumental responding for food. These findings, in conjunction with the observed impairment in excitatory transmission in the DLS, support the view that the normal learning and use of habitual action strategies depend on DLS engagement (Yin et al., 2004; Dias-Ferreira et al., 2009; Thorn et al., 2010; Smith and Graybiel, 2013). In this way, weakened excitatory drive of the DLS may bias animals toward the adoption of goal-directed strategies that are more reliant on dorsomedial striatum-based circuitry (Yin et al., 2005b; Gremel and Costa, 2013; Hart et al., 2018). Of course, in the present study, RIM1 was deleted from widespread cortical structures, including from associative and limbic cortical regions that innervate the dorsomedial striatum and ventral striatum (McGeorge and Faull, 1989; Hintiryan et al., 2016). Deletion-induced impairments in excitatory transmission may also occur in these and other regions and contribute to the array of behavioral phenotypes observed in these animals. It remains notable, however, that widespread cortical RIM1 deletion led to a net bias toward goal-directed actions. Future work mapping the synaptic phenotypes seen across striatal subregions following cortical RIM1 deletion would help to explain this net bias.

A major impetus for targeting electrophysiology recordings to the DLS was to explore the relationship between prominent forms of DLS presynaptic plasticity and action control. Indeed, prior work has proposed that CB1R-mediated LTD in the DLS plays an important role in habit expression because the two phenomena are impaired following the development of tolerance to a CB1R agonist $(\Delta 9-\mathrm{THC})$ and are rescued upon restoration of endocannabinoid signaling in the DLS (Nazzaro et al., 2012). The sparing of CB1R-mediated LTD in the DLS following RIM1 deletion did not permit direct testing of this hypothesis. However, it is probable that impairment of synaptic mechanisms other than LTD can interfere with habit learning even when LTD is normal. Indeed, multiple mechanisms are likely to contribute to overreliance or under-reliance on DLS-based circuits that can promote or impair habit learning and use (Corbit et al., 2014; Barker et al., 2015; Gremel et al., 2016; O’Hare et al., 2017). Variation in CB1R-mediated plasticity in the DLS is only one such mechanism.

Motor skill learning was also found to be impaired following cortex-wide conditional RIM1 deletion. Global RIM1 $\alpha$ KO mice showed no such impairment across a single-day rotarod training paradigm (Powell et al., 2004), but distinct methodologies (e.g., single isoform deletion, developmental compensation, extent of training, etc.) may account for these distinct behavioral phenotypes. Our evidence of impaired motor learning, paired with a deficit in DLS excitatory transmission, supports the view that like habitual responding the learning of stereotyped motor actions depends on DLS engagement (Miyachi et al., 2002; Floyer-Lea and Matthews, 2005; Yin et al., 2009). Indeed, recent work from our group showed that sensorimotor cortical inputs to DLS are robustly engaged from the outset of action learning, and incre- 
mentally disengage as actions become refined and stereotyped (Kupferschmidt et al., 2017). Findings from our group further show that conditional deletion of CB1R from cortical pyramidal neurons (in Emx1::Cre;CB1R ${ }^{-1-}$ mice) has no effect on rotarod learning (D.A.K. and D.M.L., unpublished observations). Together, these findings suggest that basal glutamate release at corticostriatal synapses (and associated postsynaptic plasticity), and not presynaptic GPCR modulation of this release, is particularly critical for motor skill learning. As above, synaptic impairments following cortical RIM1 deletion undoubtedly extend beyond those presently observed in the DLS and may contribute to the observed motor skill learning deficit.

Last, mice with the conditional RIM1 deletion showed a pronounced enhancement of the locomotor response to a novel environment. A similar enhancement was seen in global RIM1 $\alpha$ mice (Powell et al., 2004; Blundell et al., 2010), suggesting that RIM1 $\alpha$-dependent processes in forebrain excitatory neurons contribute to this behavioral phenotype. Haws et al. (2012) showed a modest increase in novelty-induced locomotion in mice with RIM1 conditionally deleted from nearly all hippocampal CA3 pyramidal neurons plus sparse populations in dentate gyrus, cerebellum, cortex, and thalamus. Therefore, the RIM1lacking neurons driving the novelty response in the present experiments may be primarily localized to the hippocampus and likely differ from those driving the impaired skill learning and biased instrumental action control. Notably, however, the neural substrates underlying novelty responses and appetitive motivational processes, like those that support instrumental responding under high-effort conditions, may show greater convergence, including a shared reliance on ventral striatal brain systems (Bardo et al., 1996; Legault and Wise, 2001; Salamone et al., 2003, 2016; Lisman and Grace, 2005). Therefore, neuroadaptations in such systems may underlie the heightened novelty-induced locomotion and PR food responding seen here in conditional RIM1 KO mice.

For reasons both technical and historical, study of the neural basis of action control has focused heavily on learning-related postsynaptic adaptations in basal ganglia circuits. However, the molecular players and physiological processes at work within targeted populations of presynaptic terminals have become accessible to modern neuroscientists, and their contributions to normal and disordered action control are becoming increasingly recognized. Here we advance this effort by revealing a selective role for presynaptic RIM1 in neurotransmitter release at a key input structure of the basal ganglia and provide evidence that RIM1dependent processes help to promote the refinement of skilled actions, constrain goal-directed behaviors, and contribute to the learning and use of habits.

\section{References}

Abrahamsson T, Chou CY, Li SY, Mancino A, Costa RP, Brock JA, Nuro E, Buchanan KA, Elgar D, Blackman AV, Tudor-Jones A, Oyrer J, Farmer WT, Murai KK, Sjöström PJ (2017) Differential regulation of evoked and spontaneous release by presynaptic NMDA receptors. Neuron 96: 839-855.e5. CrossRef Medline

Atwood BK, Kupferschmidt DA, Lovinger DM (2014) Opioids induce dissociable forms of long-term depression of excitatory inputs to the dorsal striatum. Nat Neurosci 17:540-548. CrossRef Medline

Balleine BW, Delgado MR, Hikosaka O (2007) The role of the dorsal striatum in reward and decision-making. J Neurosci 27:8161-8165. CrossRef Medline

Bardo MT, Donohew RL, Harrington NG (1996) Psychobiology of novelty seeking and drug seeking behavior. Behav Brain Res 77:23-43. CrossRef Medline

Barker JM, Corbit LH, Robinson DL, Gremel CM, Gonzales RA, Chandler LJ
(2015) Corticostriatal circuitry and habitual ethanol seeking. Alcohol 49:817-824. CrossRef Medline

Barnes TD, Kubota Y, Hu D, Jin DZ, Graybiel AM (2005) Activity of striatal neurons reflects dynamic encoding and recoding of procedural memories. Nature 437:1158-1161. CrossRef Medline

Blundell J, Kaeser PS, Südhof TC, Powell CM (2010) RIM1alpha and interacting proteins involved in presynaptic plasticity mediate prepulse inhibition and additional behaviors linked to schizophrenia. J Neurosci 30: 5326-5333. CrossRef Medline

Calabresi P, Mercuri NB, De Murtas M, Bernardi G (1990) Endogenous GABA mediates presynaptic inhibition of spontaneous and evoked excitatory synaptic potentials in the rat neostriatum. Neurosci Lett 118:99102. CrossRef Medline

Calakos N, Schoch S, Südhof TC, Malenka RC (2004) Multiple roles for the active zone protein RIMlalpha in late stages of neurotransmitter release. Neuron 42:889-896. CrossRef Medline

Castillo PE, Schoch S, Schmitz F, Südhof TC, Malenka RC (2002) RIM1alpha is required for presynaptic long-term potentiation. Nature 415:327-330. CrossRef Medline

Chevaleyre V, Heifets BD, Kaeser PS, Südhof TC, Purpura DP, Castillo PE (2007) Endocannabinoid-mediated long-term plasticity requires cAMP/ PKA signaling and RIM1alpha. Neuron 54:801-812. CrossRef Medline

Coppola T, Magnin-Luthi S, Perret-Menoud V, Gattesco S, Schiavo G, Regazzi R (2001) Direct interaction of the Rab3 effector RIM with $\mathrm{Ca}^{2+}$ channels, SNAP-25, and synaptotagmin. J Biol Chem 276:32756-32762. CrossRef Medline

Corbit LH, Leung BK, Balleine BW (2013) The role of the amygdala-striatal pathway in the acquisition and performance of goal-directed instrumental actions. J Neurosci 33:17682-17690. CrossRef Medline

Corbit LH, Chieng BC, Balleine BW (2014) Effects of repeated cocaine exposure on habit learning and reversal by $\mathrm{N}$-acetylcysteine. Neuropsychopharmacology 39:1893-1901. CrossRef Medline

Costa RM, Cohen D, Nicolelis MA (2004) Differential corticostriatal plasticity during fast and slow motor skill learning in mice. Curr Biol 14: 1124-1134. CrossRef Medline

Dang MT, Yokoi F, Yin HH, Lovinger DM, Wang Y, Li Y (2006) Disrupted motor learning and long-term synaptic plasticity in mice lacking NMDAR1 in the striatum. Proc Natl Acad Sci U S A 103:15254-15259. CrossRef Medline

Davis MI, Crittenden JR, Feng AY, Kupferschmidt DA, Naydenov A, Stella N, Graybiel AM, Lovinger DM (2018) The cannabinoid-1 receptor is abundantly expressed in striatal striosomes and striosome-dendron bouquets of the substantia nigra. PLoS One 13:e0191436. CrossRef Medline

Deng L, Kaeser PS, Xu W, Südhof TC (2011) RIM proteins activate vesicle priming by reversing autoinhibitory homodimerization of Munc13. Neuron 69:317-331. CrossRef Medline

Derusso AL, Fan D, Gupta J, Shelest O, Costa RM, Yin HH (2010) Instrumental uncertainty as a determinant of behavior under interval schedules of reinforcement. Front Integr Neurosci 4:17. CrossRef Medline

Dias-Ferreira E, Sousa JC, Melo I, Morgado P, Mesquita AR, Cerqueira JJ, Costa RM, Sousa N (2009) Chronic stress causes frontostriatal reorganization and affects decision-making. Science 325:621-625. CrossRef Medline

Dickinson A (1985) Actions and habits: the development of behavioural autonomy. Philos Trans R Soc Lond B Biol Sci 308:67-78. CrossRef

Ding J, Peterson JD, Surmeier DJ (2008) Corticostriatal and thalamostriatal synapses have distinctive properties. J Neurosci 28:6483-6492. CrossRef Medline

Floyer-Lea A, Matthews PM (2005) Distinguishable brain activation networks for short- and long-term motor skill learning. J Neurophysiol 94: 512-518. CrossRef Medline

Fourcaudot E, Gambino F, Humeau Y, Casassus G, Shaban H, Poulain B, Lüthi A (2008) cAMP/PKA signaling and RIMlalpha mediate presynaptic LTP in the lateral amygdala. Proc Natl Acad Sci U S A 105:1513015135. CrossRef Medline

Gerdeman GL, Ronesi J, Lovinger DM (2002) Postsynaptic endocannabinoid release is critical to long-term depression in the striatum. Nat Neurosci 5:446-451. CrossRef Medline

Gorski JA, Talley T, Qiu M, Puelles L, Rubenstein JL, Jones KR (2002) Cortical excitatory neurons and glia, but not GABAergic neurons, are produced in the Emx1-expressing lineage. J Neurosci 22:6309-6314. CrossRef Medline 
Graybiel AM, Grafton ST (2015) The striatum: where skills and habits meet. Cold Spring Harb Perspect Biol 7:a021691. CrossRef Medline

Gremel CM, Costa RM (2013) Orbitofrontal and striatal circuits dynamically encode the shift between goal-directed and habitual actions. Nat Commun 4:2264. CrossRef Medline

Gremel CM, Chancey JH, Atwood BK, Luo G, Neve R, Ramakrishnan C, Deisseroth K, Lovinger DM, Costa RM (2016) Endocannabinoid modulation of orbitostriatal circuits gates habit formation. Neuron 90:13121324. CrossRef Medline

Grueter BA, Brasnjo G, Malenka RC (2010) Postsynaptic TRPV1 triggers cell type-specific long-term depression in the nucleus accumbens. Nat Neurosci 13:1519-1525. CrossRef Medline

Han Y, Kaeser PS, Südhof TC, Schneggenburger R (2011) RIM determines $\mathrm{Ca}(2)+$ channel density and vesicle docking at the presynaptic active zone. Neuron 69:304-316. CrossRef Medline

Hart G, Bradfield LA, Balleine BW (2018) Prefrontal corticostriatal disconnection blocks the acquisition of goal-directed action. J Neurosci 38: 1311-1322. CrossRef Medline

Hawes SL, Evans RC, Unruh BA, Benkert EE, Gillani F, Dumas TC, Blackwell KT (2015) Multimodal plasticity in dorsal striatum while learning a lateralized navigation task. J Neurosci 35:10535-10549. CrossRef Medline

Haws ME, Kaeser PS, Jarvis DL, Südhof TC, Powell CM (2012) Regionspecific deletions of RIM1 reproduce a subset of global RIM1alpha (-/-) phenotypes. Genes Brain Behav 11:201-213. CrossRef Medline

Heilbronner SR, Rodriguez-Romaguera J, Quirk GJ, Groenewegen HJ, Haber SN (2016) Circuit-based corticostriatal homologies between rat and primate. Biol Psychiatry 80:509-521. CrossRef Medline

Hibino H, Pironkova R, Onwumere O, Vologodskaia M, Hudspeth AJ, Lesage F (2002) RIM binding proteins (RBPs) couple Rab3-interacting molecules (RIMs) to voltage-gated $\mathrm{Ca}(2+)$ channels. Neuron 34:411-423. CrossRef Medline

Hintiryan H, Foster NN, Bowman I, Bay M, Song MY, Gou L, Yamashita S, Bienkowski MS, Zingg B, Zhu M, Yang XW, Shih JC, Toga AW, Dong HW (2016) The mouse cortico-striatal projectome. Nat Neurosci 19:11001114. CrossRef Medline

Huerta-Ocampo I, Mena-Segovia J, Bolam JP (2014) Convergence of corti$\mathrm{cal}$ and thalamic input to direct and indirect pathway medium spiny neurons in the striatum. Brain Struct Funct 219:1787-1800. CrossRef Medline

Hunnicutt BJ, Long BR, Kusefoglu D, Gertz KJ, Zhong H, Mao T (2014) A comprehensive thalamocortical projection map at the mesoscopic level. Nat Neurosci 17:1276-1285. CrossRef Medline

Hunnicutt BJ, Jongbloets BC, Birdsong WT, Gertz KJ, Zhong H, Mao T (2016) A comprehensive excitatory input map of the striatum reveals novel functional organization. Elife 5:19103. CrossRef Medline

Johnson KA, Mateo Y, Lovinger DM (2017) Metabotropic glutamate receptor 2 inhibits thalamically-driven glutamate and dopamine release in the dorsal striatum. Neuropharmacology 117:114-123. CrossRef Medline

Kaeser PS, Kwon HB, Chiu CQ, Deng L, Castillo PE, Südhof TC (2008a) RIMlalpha and RIMlbeta are synthesized from distinct promoters of the RIM1 gene to mediate differential but overlapping synaptic functions. J Neurosci 28:13435-13447. CrossRef Medline

Kaeser PS, Kwon HB, Blundell J, Chevaleyre V, Morishita W, Malenka RC, Powell CM, Castillo PE, Südhof TC (2008b) RIMlalpha phosphorylation at serine- 413 by protein kinase $\mathrm{A}$ is not required for presynaptic long-term plasticity or learning. Proc Natl Acad Sci U S A 105:1468014685. CrossRef Medline

Kaeser PS, Deng L, Wang Y, Dulubova I, Liu X, Rizo J, Südhof TC (2011) RIM proteins tether $\mathrm{Ca}^{2+}$ channels to presynaptic active zones via a direct PDZ-domain interaction. Cell 144:282-295. CrossRef Medline

Kelley AE, Domesick VB, Nauta WJ (1982) The amygdalostriatal projection in the rat-an anatomical study by anterograde and retrograde tracing methods. Neuroscience 7:615-630. CrossRef Medline

Kheirbek MA, Britt JP, Beeler JA, Ishikawa Y, McGehee DS, Zhuang X (2009) Adenylyl cyclase type 5 contributes to corticostriatal plasticity and striatum-dependent learning. J Neurosci 29:12115-12124. CrossRef Medline

Kintscher M, Wozny C, Johenning FW, Schmitz D, Breustedt J (2013) Role of RIM1alpha in short- and long-term synaptic plasticity at cerebellar parallel fibres. Nat Commun 4:2392. CrossRef Medline

Kiyonaka S, Wakamori M, Miki T, Uriu Y, Nonaka M, Bito H, Beedle AM, Mori E, Hara Y, De Waard M, Kanagawa M, Itakura M, Takahashi M,
Campbell KP, Mori Y (2007) RIM1 confers sustained activity and neurotransmitter vesicle anchoring to presynaptic $\mathrm{Ca}^{2+}$ channels. Nat Neurosci 10:691-701. CrossRef Medline

Kreitzer AC, Malenka RC (2005) Dopamine modulation of state-dependent endocannabinoid release and long-term depression in the striatum. J Neurosci 25:10537-10545. CrossRef Medline

Kupferschmidt DA, Lovinger DM (2015) Inhibition of presynaptic calcium transients in cortical inputs to the dorsolateral striatum by metabotropic GABA(B) and mGlu2/3 receptors. J Physiol 593:2295-2310. CrossRef Medline

Kupferschmidt DA, Juczewski K, Cui G, Johnson KA, Lovinger DM (2017) Parallel, but dissociable, processing in discrete corticostriatal inputs encodes skill learning. Neuron 96:476-489.e5. CrossRef Medline

Legault M, Wise RA (2001) Novelty-evoked elevations of nucleus accumbens dopamine: dependence on impulse flow from the ventral subiculum and glutamatergic neurotransmission in the ventral tegmental area. Eur J Neurosci 13:819-828. CrossRef Medline

Lisman JE, Grace AA (2005) The hippocampal-VTA loop: controlling the entry of information into long-term memory. Neuron 46:703-713. CrossRef Medline

Lonart G, Schoch S, Kaeser PS, Larkin CJ, Südhof TC, Linden DJ (2003) Phosphorylation of RIMlalpha by PKA triggers presynaptic long-term potentiation at cerebellar parallel fiber synapses. Cell 115:49-60. CrossRef Medline

Lovinger DM (1991) Trans-1-aminocyclopentane-1,3-dicarboxylic acid (tACPD) decreases synaptic excitation in rat striatal slices through a presynaptic action. Neurosci Lett 129:17-21. CrossRef Medline

Lovinger DM (2010) Neurotransmitter roles in synaptic modulation, plasticity and learning in the dorsal striatum. Neuropharmacology 58:951961. CrossRef Medline

Mathur BN, Capik NA, Alvarez VA, Lovinger DM (2011) Serotonin induces long-term depression at corticostriatal synapses. J Neurosci 31:74027411. CrossRef Medline

McGeorge AJ, Faull RL (1989) The organization of the projection from the cerebral cortex to the striatum in the rat. Neuroscience 29:503-537. CrossRef Medline

Miyachi S, Hikosaka O, Lu X (2002) Differential activation of monkey striatal neurons in the early and late stages of procedural learning. Exp Brain Res 146:122-126. CrossRef Medline

Nazzaro C, Greco B, Cerovic M, Baxter P, Rubino T, Trusel M, Parolaro D, Tkatch T, Benfenati F, Pedarzani P, Tonini R (2012) SK channel modulation rescues striatal plasticity and control over habit in cannabinoid tolerance. Nat Neurosci 15:284-293. CrossRef Medline

O'Hare JK, Li H, Kim N, Gaidis E, Ade K, Beck J, Yin H, Calakos N (2017) Striatal fast-spiking interneurons selectively modulate circuit output and are required for habitual behavior. Elife 6:26231. CrossRef Medline

Park H, Popescu A, Poo MM (2014) Essential role of presynaptic NMDA receptors in activity-dependent BDNF secretion and corticostriatal LTP. Neuron 84:1009-1022. CrossRef Medline

Peak J, Hart G, Balleine BW (2018) From learning to action: the integration of dorsal striatal input and output pathways in instrumental conditioning. Eur J Neurosci. Advance online publication. Retrieved May 23, 2018. doi: 10.1111/ejn.13964.

Pittenger C, Fasano S, Mazzocchi-Jones D, Dunnett SB, Kandel ER, Brambilla R (2006) Impaired bidirectional synaptic plasticity and procedural memory formation in striatum-specific cAMP response element-binding protein-deficient mice. J Neurosci 26:2808-2813. CrossRef Medline

Powell CM, Schoch S, Monteggia L, Barrot M, Matos MF, Feldmann N, Südhof TC, Nestler EJ (2004) The presynaptic active zone protein RIM1alpha is critical for normal learning and memory. Neuron 42:143153. CrossRef Medline

Richardson NR, Roberts DC (1996) Progressive ratio schedules in drug selfadministration studies in rats: a method to evaluate reinforcing efficacy. J Neurosci Methods 66:1-11. CrossRef Medline

Rueda-Orozco PE, Robbe D (2015) The striatum multiplexes contextual and kinematic information to constrain motor habits execution. Nat Neurosci 18:453-460. CrossRef Medline

Russo SJ, Dietz DM, Dumitriu D, Morrison JH, Malenka RC, Nestler EJ (2010) The addicted synapse: mechanisms of synaptic and structural plasticity in nucleus accumbens. Trends Neurosci 33:267-276. CrossRef Medline

Salamone JD, Correa M, Mingote S, Weber SM (2003) Nucleus accumbens 
dopamine and the regulation of effort in food-seeking behavior: implications for studies of natural motivation, psychiatry, and drug abuse. J Pharmacol Exp Ther 305:1-8. CrossRef Medline

Salamone JD, Pardo M, Yohn SE, López-Cruz L, SanMiguel N, Correa M (2016) Mesolimbic dopamine and the regulation of motivated behavior. Curr Top Behav Neurosci 27:231-257. CrossRef Medline

Santos FJ, Oliveira RF, Jin X, Costa RM (2015) Corticostriatal dynamics encode the refinement of specific behavioral variability during skill learning. Elife 4:e09423. CrossRef Medline

Schmittgen TD, Livak KJ (2008) Analyzing real-time PCR data by the comparative C(T) method. Nat Protoc 3:1101-1108. CrossRef Medline

Schoch S, Castillo PE, Jo T, Mukherjee K, Geppert M, Wang Y, Schmitz F, Malenka RC, Südhof TC (2002) RIMlalpha forms a protein scaffold for regulating neurotransmitter release at the active zone. Nature 415:321326. CrossRef Medline

Schoch S, Mittelstaedt T, Kaeser PS, Padgett D, Feldmann N, Chevaleyre V, Castillo PE, Hammer RE, Han W, Schmitz F, Lin W, Südhof TC (2006) Redundant functions of RIMlalpha and RIM2alpha in $\mathrm{Ca}(2+)$-triggered neurotransmitter release. EMBO J 25:5852-5863. CrossRef Medline

Shonesy BC, Wang X, Rose KL, Ramikie TS, Cavener VS, Rentz T, Baucum AJ 2nd, Jalan-Sakrikar N, Mackie K, Winder DG, Patel S, Colbran RJ (2013) CaMKII regulates diacylglycerol lipase-alpha and striatal endocannabinoid signaling. Nat Neurosci 16:456-463. CrossRef Medline

Smith KS, Graybiel AM (2013) A dual operator view of habitual behavior reflecting cortical and striatal dynamics. Neuron 79:361-374. CrossRef Medline

Smith Y, Raju DV, Pare JF, Sidibe M (2004) The thalamostriatal system: a highly specific network of the basal ganglia circuitry. Trends Neurosci 27:520-527. CrossRef Medline

Südhof TC (2013) Neurotransmitter release: the last millisecond in the life of a synaptic vesicle. Neuron 80:675-690. CrossRef Medline

Sun L, Bittner MA, Holz RW (2003) Rim, a component of the presynaptic active zone and modulator of exocytosis, binds 14-3-3 through its $\mathrm{N}$ terminus. J Biol Chem 278:38301-38309. CrossRef Medline
Thomson AM (2000) Facilitation, augmentation and potentiation at central synapses. Trends Neurosci 23:305-312. CrossRef Medline

Thorn CA, Atallah H, Howe M, Graybiel AM (2010) Differential dynamics of activity changes in dorsolateral and dorsomedial striatal loops during learning. Neuron 66:781-795. CrossRef Medline

Wang Y, Okamoto M, Schmitz F, Hofmann K, Südhof TC (1997) Rim is a putative Rab3 effector in regulating synaptic-vesicle fusion. Nature 388 : 593-598. CrossRef Medline

Wilson CJ (1995) The contribution of cortical neurons to the firing pattern of striatal spiny neurons. In Models of information processing in the basal ganglia (Houk JC, Davis JL, Beiser DG, eds), pp 29-50. Cambridge, MA: Massachusetts Institute of Technology.

Wu YW, Kim JI, Tawfik VL, Lalchandani RR, Scherrer G, Ding JB (2015) Input- and cell-type-specific endocannabinoid-dependent LTD in the striatum. Cell Rep 10:75-87. CrossRef Medline

Yang Y, Calakos N (2010) Acute in vivo genetic rescue demonstrates that phosphorylation of RIM1alpha serine 413 is not required for mossy fiber long-term potentiation. J Neurosci 30:2542-2546. CrossRef Medline

Yin HH, Knowlton BJ, Balleine BW (2004) Lesions of dorsolateral striatum preserve outcome expectancy but disrupt habit formation in instrumental learning. Eur J Neurosci 19:181-189. CrossRef Medline

Yin HH, Knowlton BJ, Balleine BW (2005a) Blockade of NMDA receptors in the dorsomedial striatum prevents action-outcome learning in instrumental conditioning. Eur J Neurosci 22:505-512. CrossRef Medline

Yin HH, Ostlund SB, Knowlton BJ, Balleine BW (2005b) The role of the dorsomedial striatum in instrumental conditioning. Eur J Neurosci 22: 513-523. CrossRef Medline

Yin HH, Knowlton BJ, Balleine BW (2006) Inactivation of dorsolateral striatum enhances sensitivity to changes in the action-outcome contingency in instrumental conditioning. Behav Brain Res 166:189-196. CrossRef Medline

Yin HH, Mulcare SP, Hilário MR, Clouse E, Holloway T, Davis MI, Hansson AC, Lovinger DM, Costa RM (2009) Dynamic reorganization of striatal circuits during the acquisition and consolidation of a skill. Nat Neurosci 12:333-341. CrossRef Medline 